Emplily U. Tnппијшіи

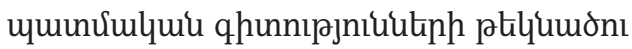

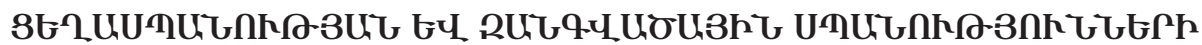

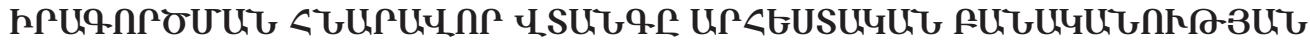 RUPQU8UU, SUUUSG.PUSกト ${ }^{1}$
}

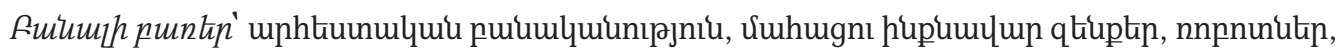

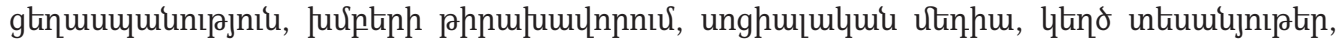
uphtuunulyui puimumunıрuiu sphlu:

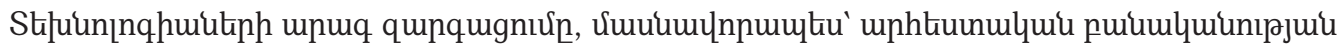

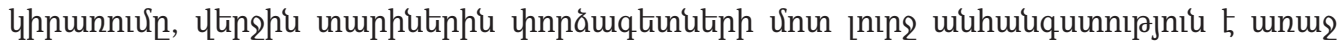

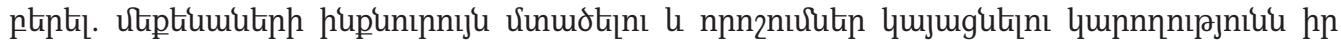

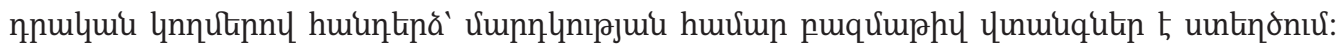

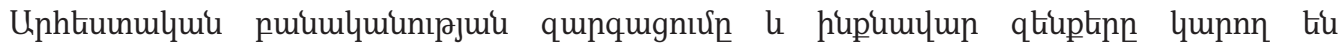

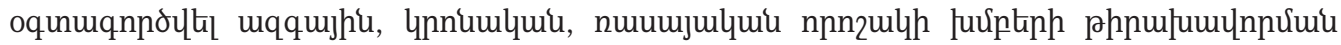

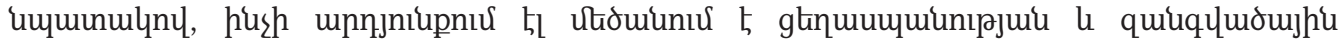

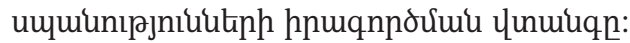

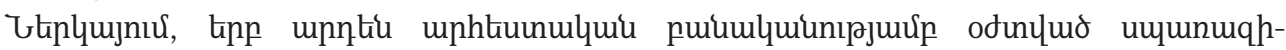

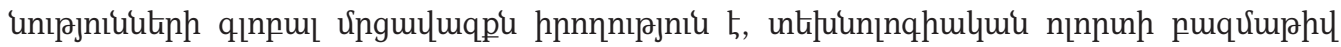

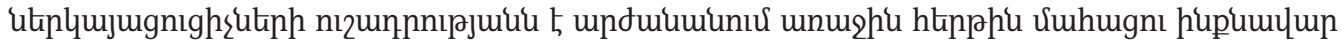

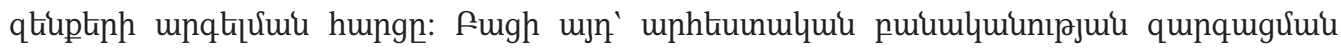

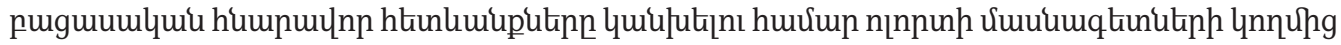

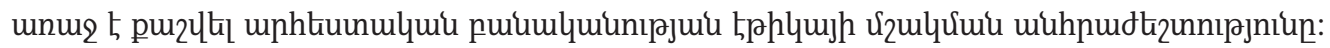

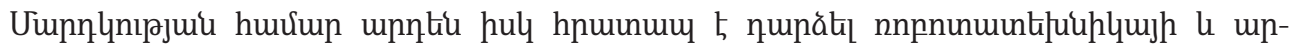

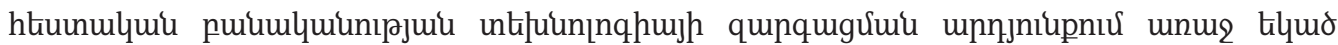

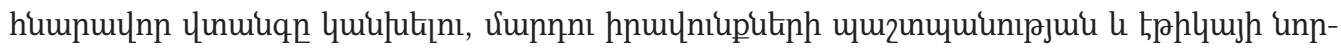

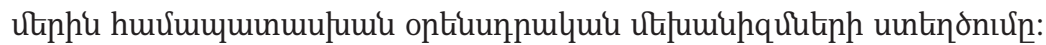

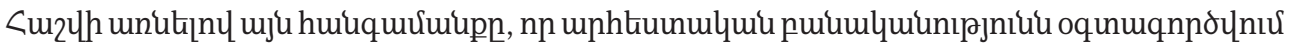

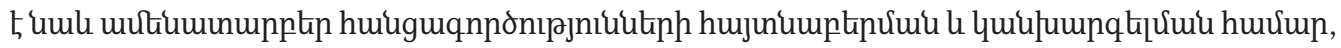

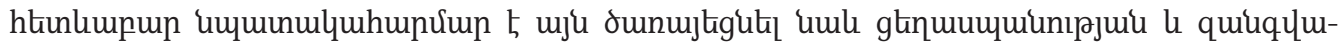

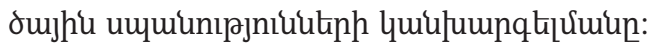

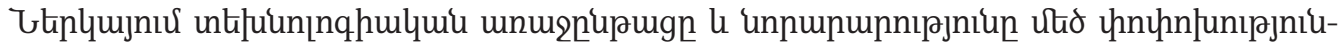

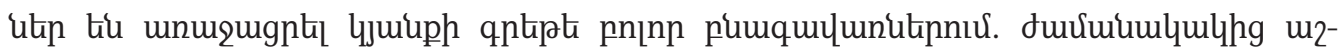

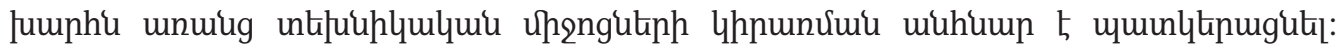

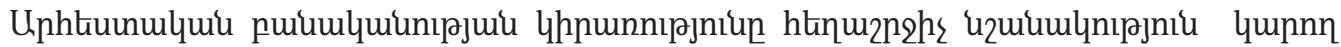

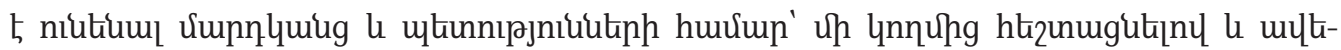

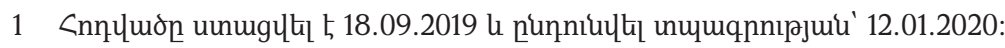




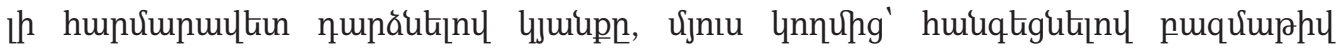

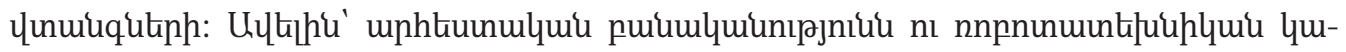

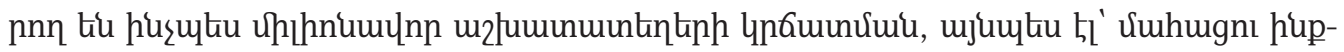
umulup qtiuptiph lhpunर्umu umunfiun nunimu:

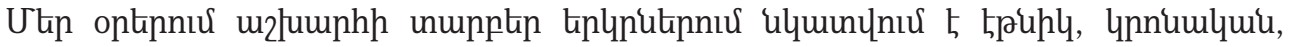

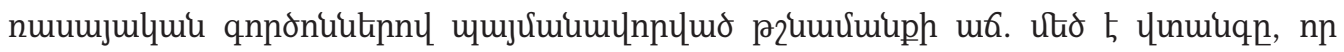

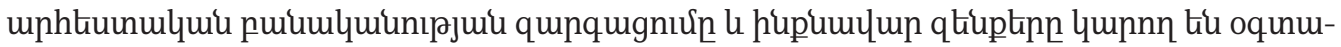

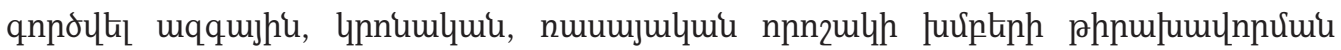

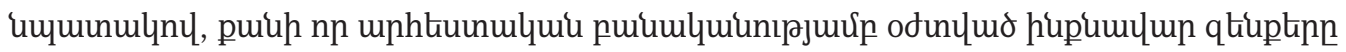

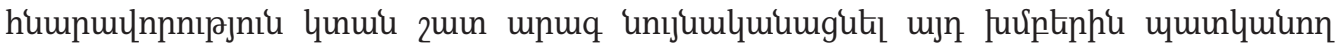

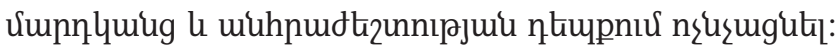

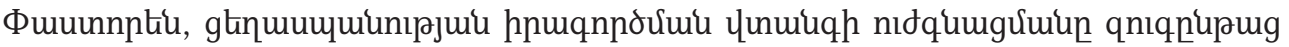

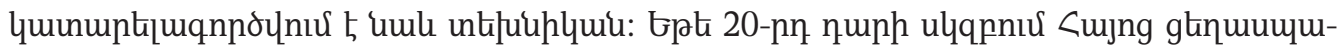

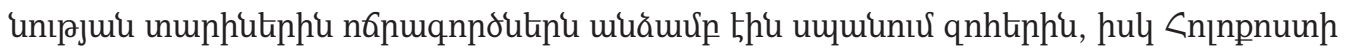

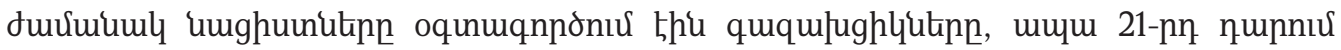

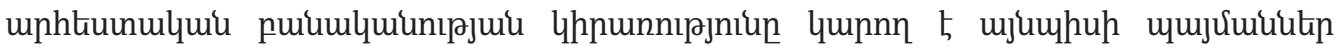

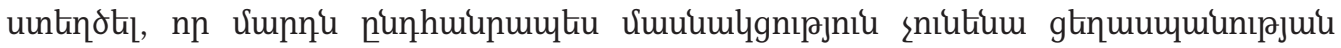

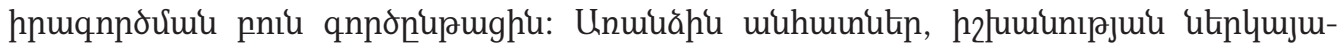

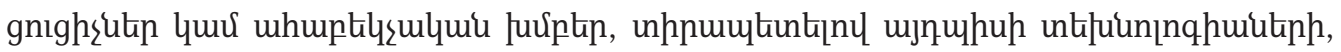

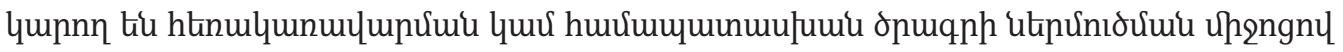

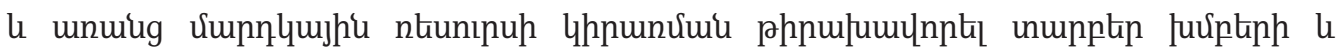

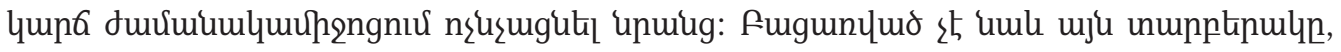

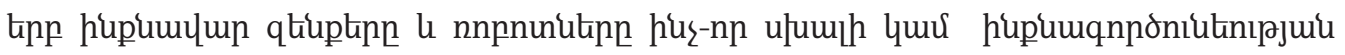

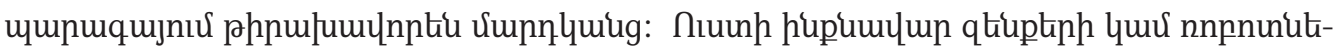

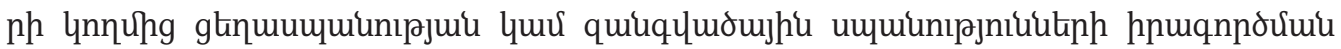

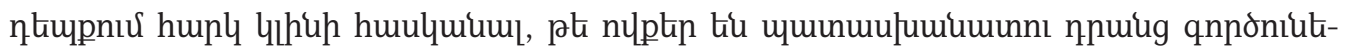

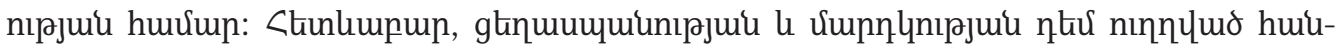

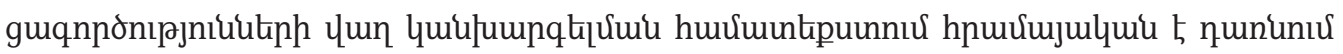

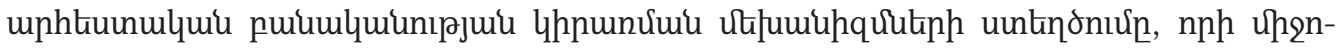

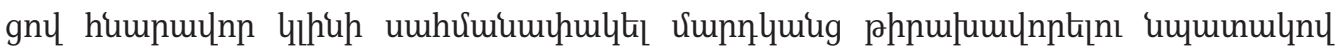

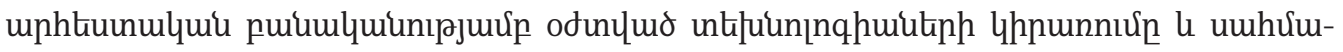

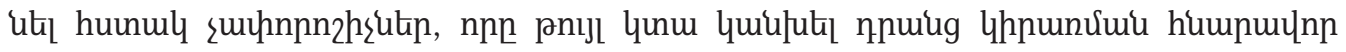
unumuqutipn:

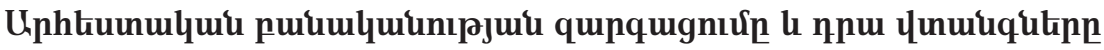 vumplynıjui hứup}

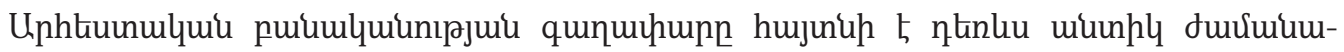

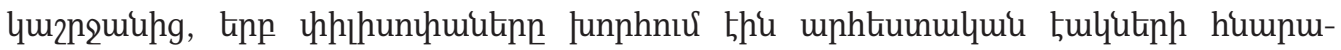

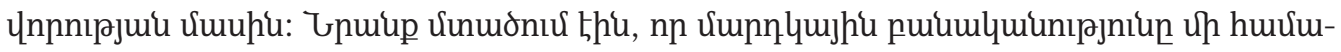




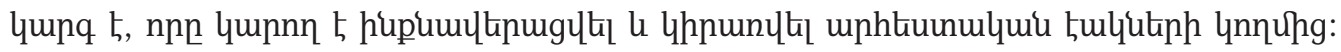

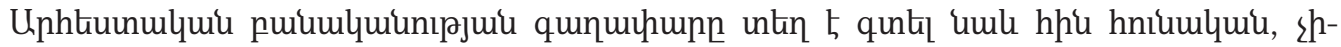

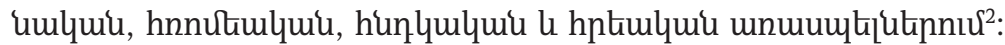

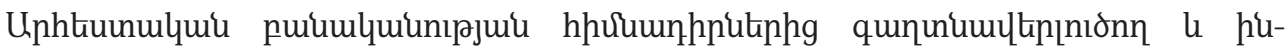

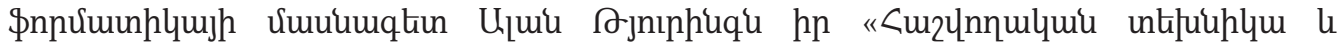

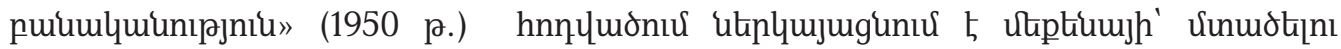

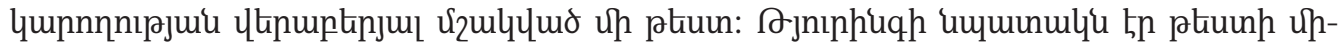

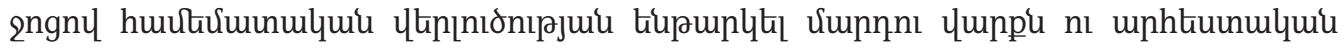

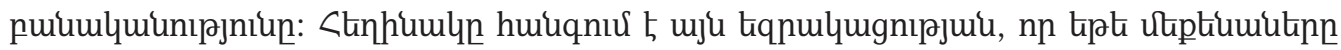

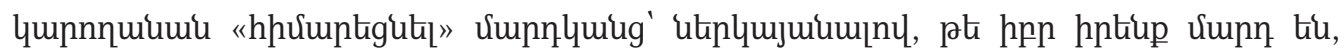

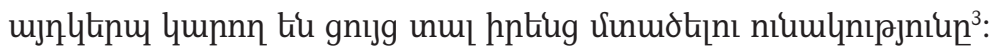

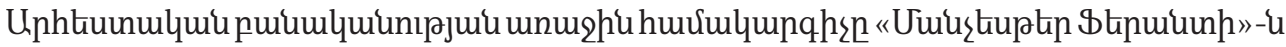

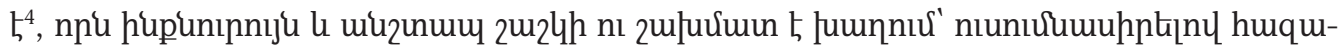

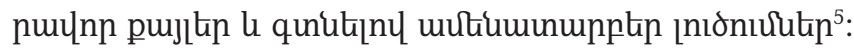

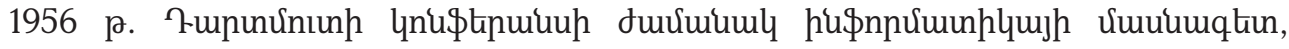

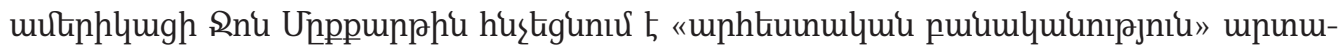

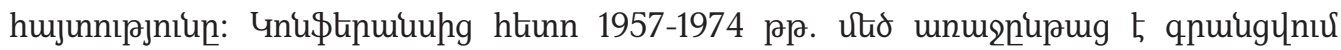

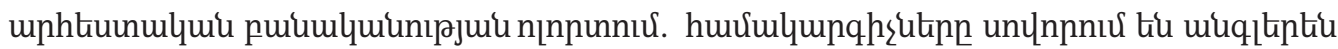

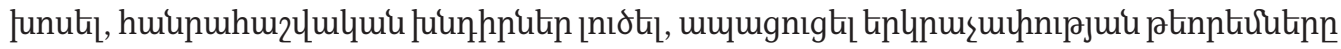
u ujlit ${ }^{6}$ :

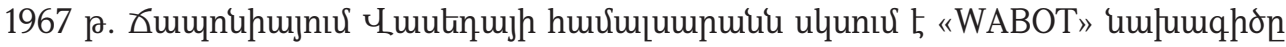

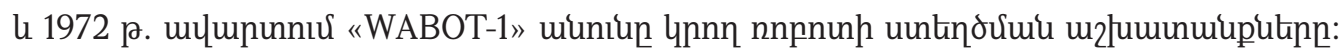

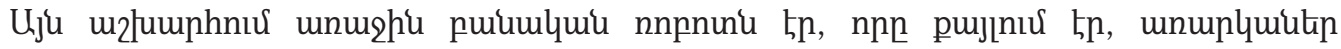

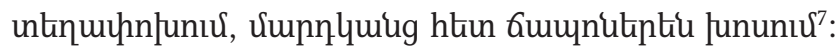

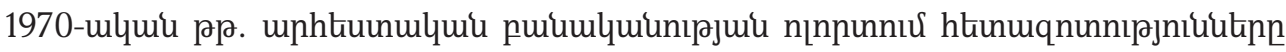

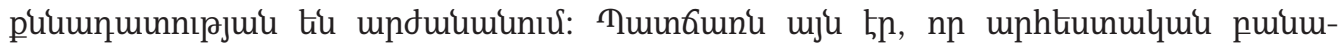

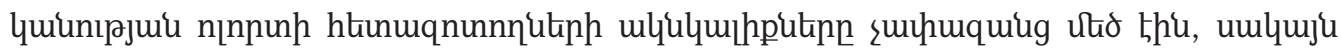

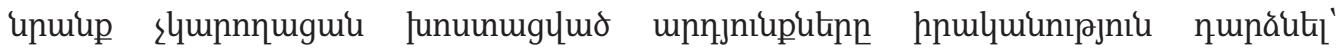

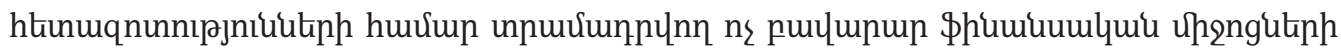

2 Adrienne Mayor, Gods and Robots: Myths, Machines, and Ancient Dreams of Technology (Princeton: Princeton University Press, 2018), 304; Donald J. Norris, Beginning Artificial Intelligence with the Raspberry Pi (Barrington: Apress, 2017), 1-2.

3 Alan Turing, "Computing Machinery and Intelligence," Mind LIX, no. 236 (1950): 433-460.

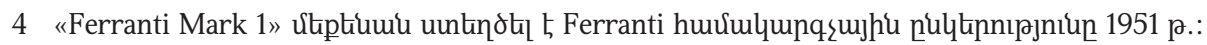

5 Tim Jones, Artificial Intelligence: A Systems Approach: A Systems Approach (Boston, Toronto, London, Singapore: Jones \& Bartlett Learning, 2015), 4-5.

6 Mark Skilton, Felix Hovsepian, The 4th Industrial Revolution: Responding to the Impact of Artificial Intelligence on Business (Cham: Springer, 2017), 76.

7 Christopher McFadden, "15 Engineers and Their Inventions That Defined Robotics," Interesting Engineering, July 06, 2018, https://interestingengineering.com/15-engineers-and-their-inventions-thatdefined-robotics, nhunцtı̆ 5 07.08.2019: 


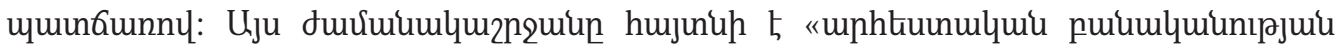
ăulin uuniunu» (1974-1980 pр.)

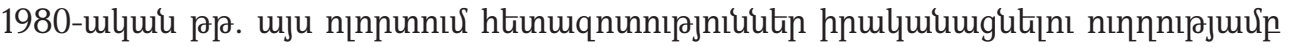

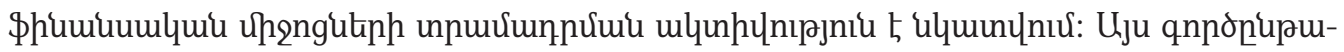

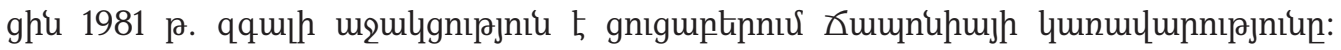

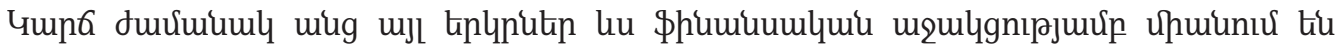

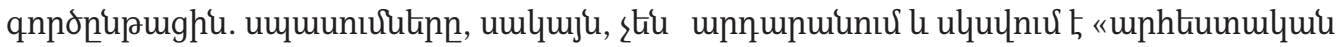

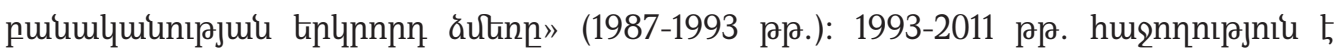

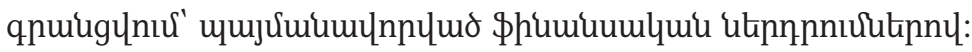

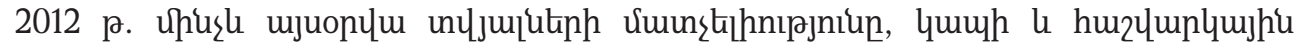

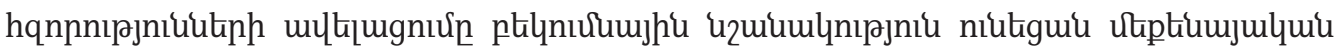
nıunıgưuu (Machine learning), utjnnumujhu guightph $\mathrm{l}$ junppujhu nıunıviuu (Deep

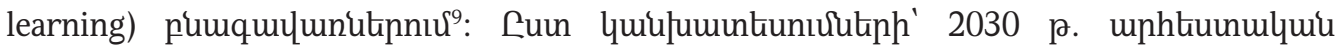

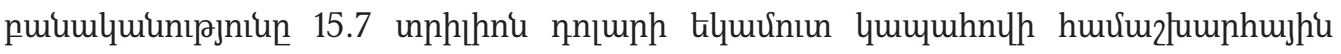
unuukiunıрjuiup ${ }^{10}$ :

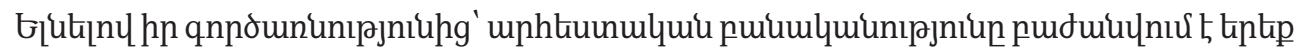

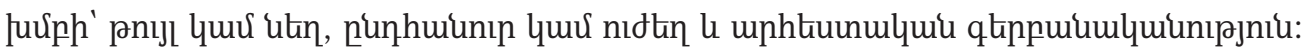

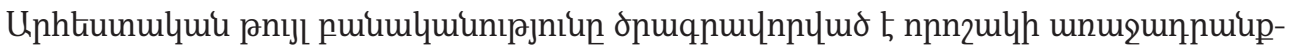

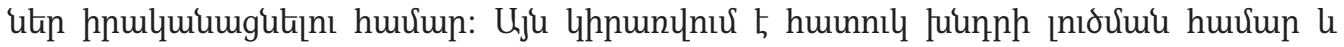

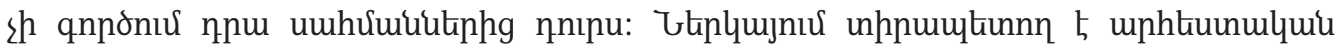

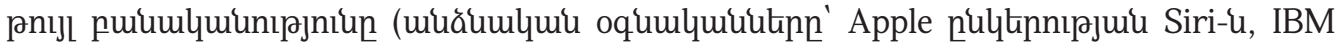

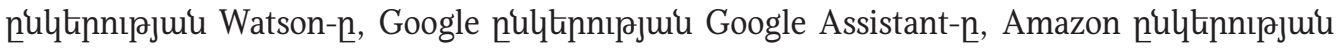

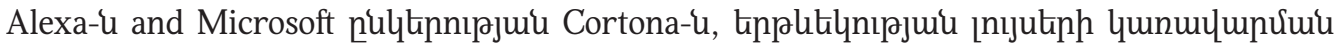

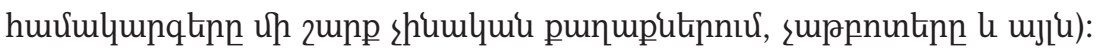

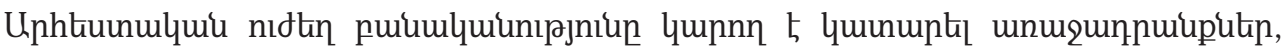

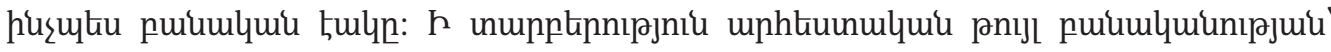

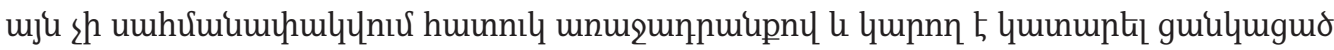

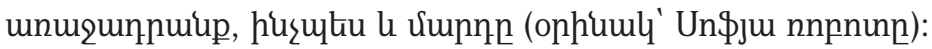

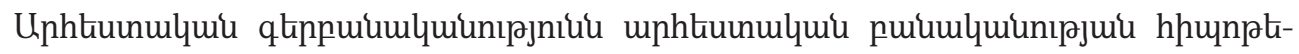

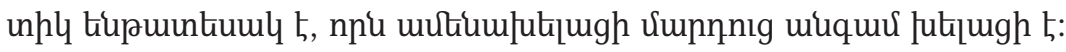

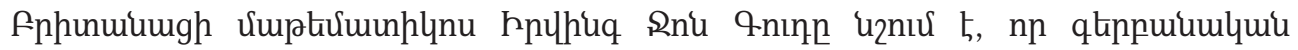

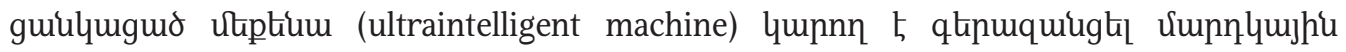

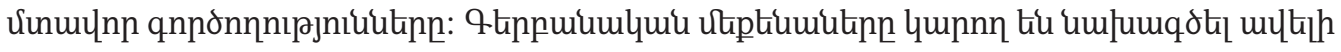

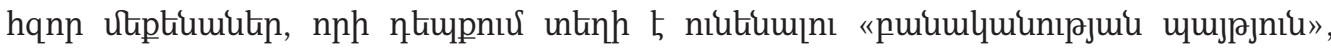

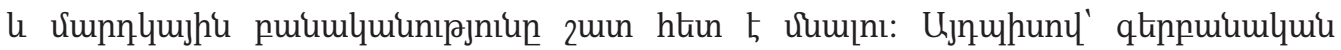

8 Tony Boobier, Advanced Analytics and AI: Impact, Implementation, and the Future of Work (Chichester: John Wiley \& Sons, 2018), 41.

9 WIPO Technology Trends 2019 - Artificial Intelligence (Geneva: WIPO, 2019), 19.

10 Anand S. Rao, Gerard Verweij, Sizing the prize What's the real value of AI for your business and how can you capitalise? https://www.pwc.com/gx/en/issues/analytics/assets/pwc-ai-analysis-sizing-the-prizereport.pdf, nhunltil 5 17.09.2019: 


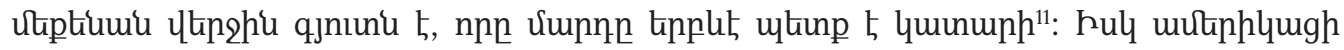

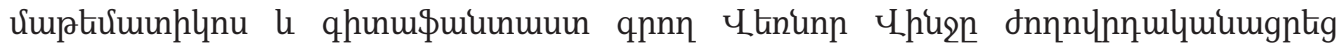

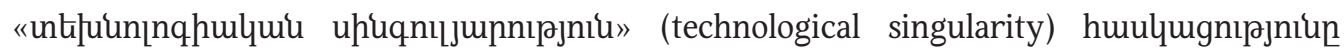

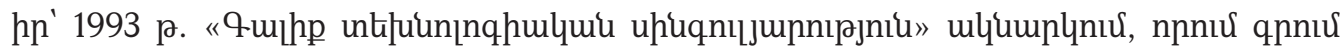

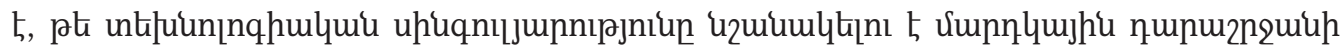

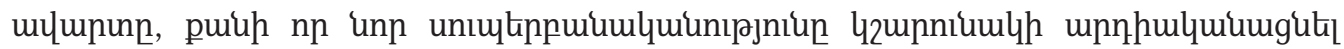

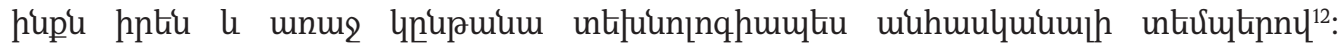

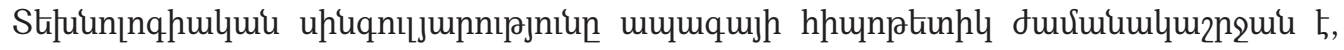

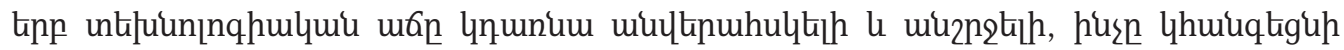

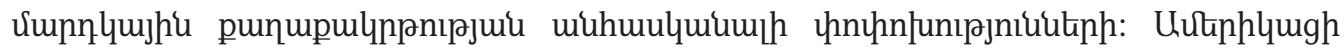

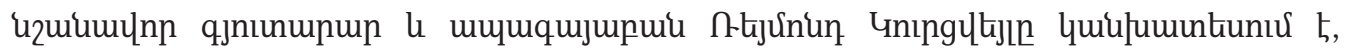

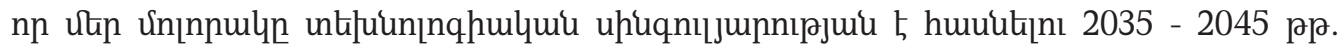

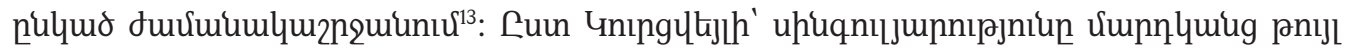

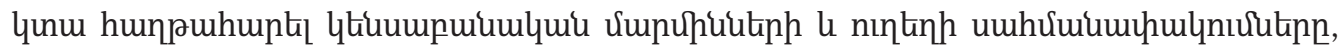

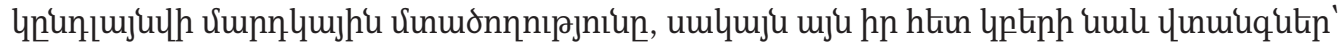

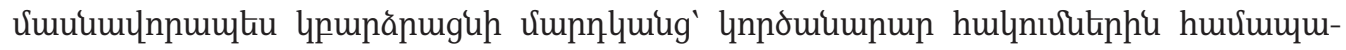

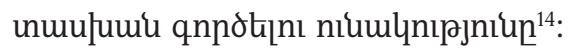

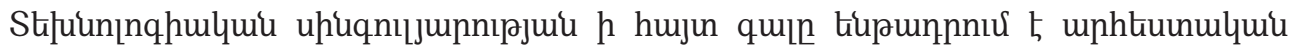

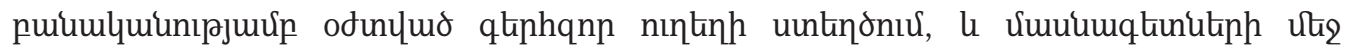

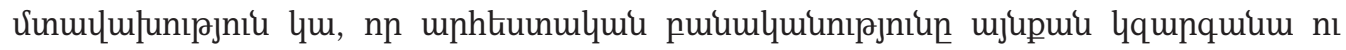

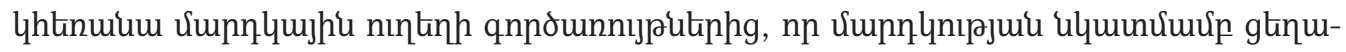

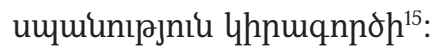

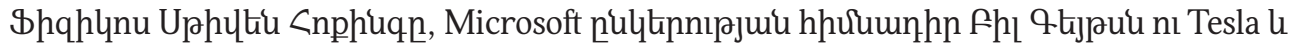

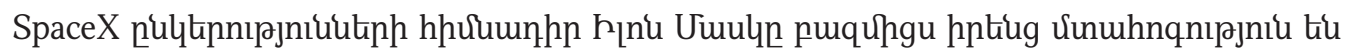

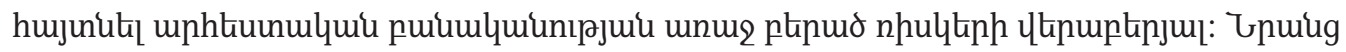

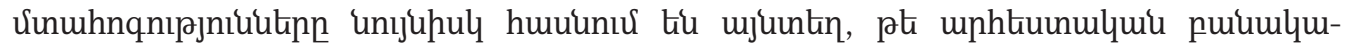

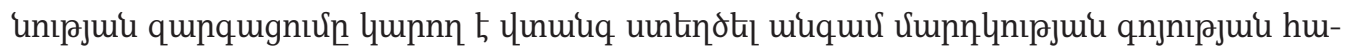

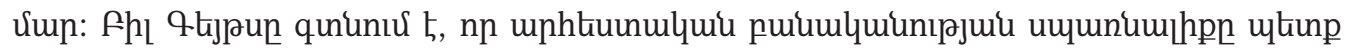

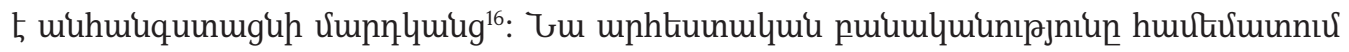

11 Irving John Good, Speculations Concerning the First Ultra intelligent Machine (Trinity College, Oxford and Atlas Computer Laboratory, Chilton, Berkshire: Elsevier, 1965), 33.

12 Vinge Vernor, "The Coming Technological Singularity: How to Survive in the Post-Human Era," in Vision-21: Interdisciplinary Science and Engineering in the Era of Cyberspace, ed. Geoffrey Landis (NASA Publication CP-10129, 1993), 11-22, https://mindstalk.net/vinge/vinge-sing.html, nhunulil 5 04.05.2019:

13 Charles Jennings, Artificial Intelligence: Rise of the Lightspeed Learners (Lanham, London: Rowman \& Littlefield, 2019), 32.

14 Ray Kurzweil, The Singularity Is Near: When Humans Transcend Biology (London: Penguin Books, 2005), 25, 34.

15 “Is Technological Evolution Infinite or Finite?" October 15, 2013, https://futurism.com/is-technologicalevolution-infinite-or-finite, nhunltil 5 10.05.2019:

16 Kevin Rawlinson, "Microsoft's Bill Gates insists AI is a threat," BBC, January 29, 2015, https://www. bbc.com/news/31047780, nhunltil 5 10.05.2019: 


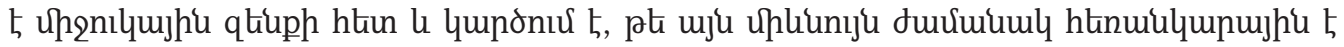

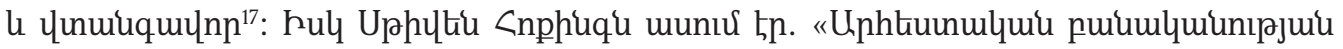

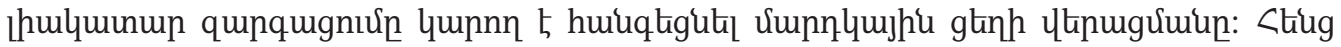

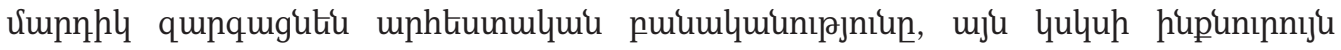

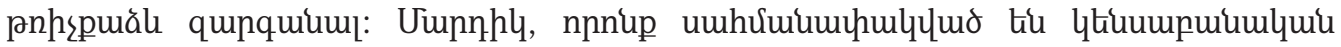

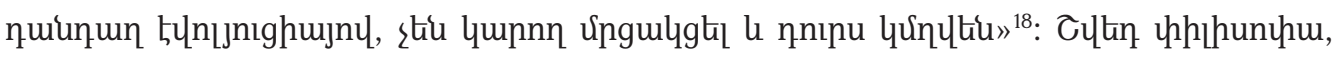

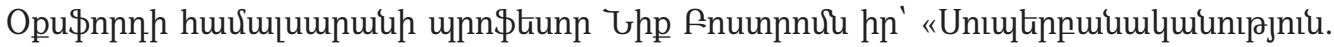

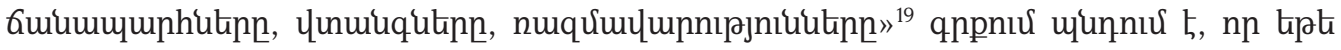

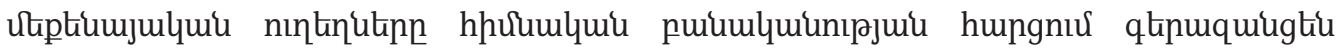

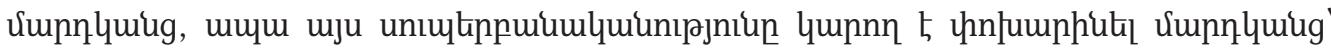

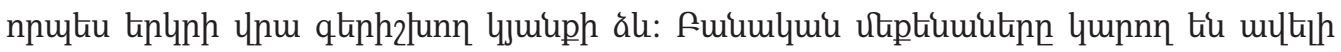

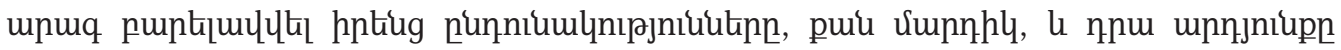

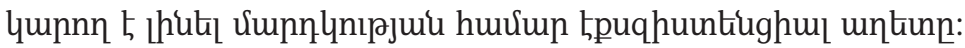

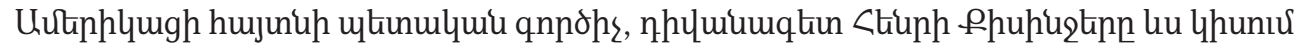

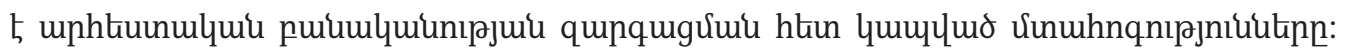

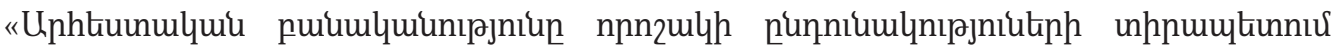

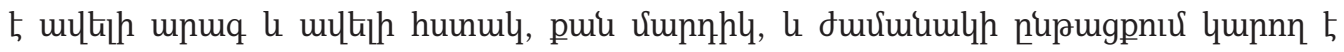

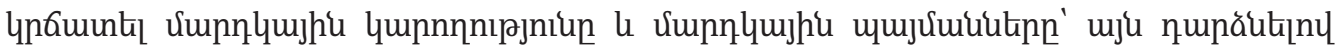

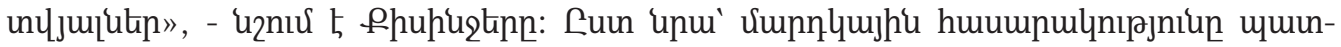

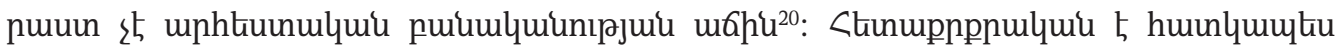

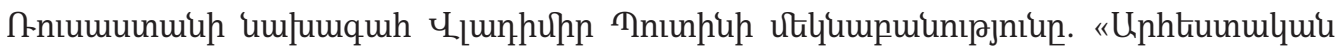

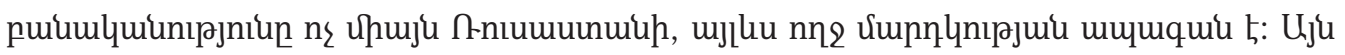

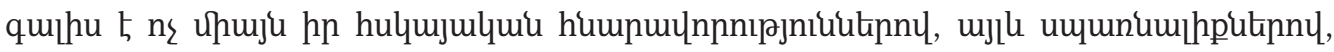

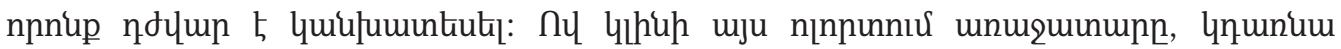

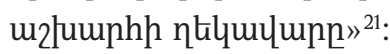

17 Jon Christian, "Bill Gates Compares Artificial Intelligence to Nuclear Weapons," March 19, 2019, https:// futurism.com/bill-gates-artificial-intelligence-nuclear-weapons, nhunц니 5 10.05.2019:

18 Cellan-Jones Rory, "Stephen Hawking warns artificial intelligence could end mankind," $B B C$, December 2, 2014, https://www.bbc.com/news/technology-30290540, nhunllil 5 10.05.2019:

19 Nick Bostrom, Superintelligence: Paths, Dangers, Strategies (Oxford: Oxford University Press, 2014), 352.

20 Henry Kissinger, "How the Enlightenment Ends: Philosophically, intellectually - in every way - human society is unprepared for the rise of artificial intelligence," The Atlantic, June 2018, https://www.theatlantic. com/magazine/archive/2018/06/henry-kissinger-ai-could-mean-the-end-of-human-history/559124/, nhunlıl § 10.05.2019:

21 Alexei Druzhinin, “'Whoever leads in AI will rule the world': Putin to Russian children on Knowledge Day," Russia Today, September 1, 2017, https://www.rt.com/news/401731-ai-rule-world-putin/, nhunlkl 12.05.2019: 


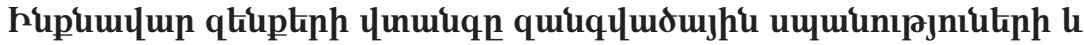

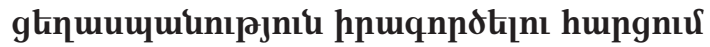

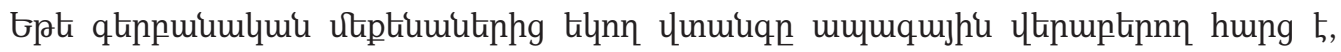

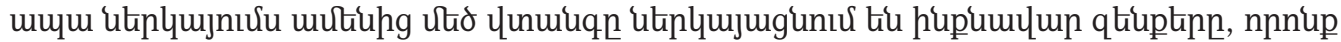

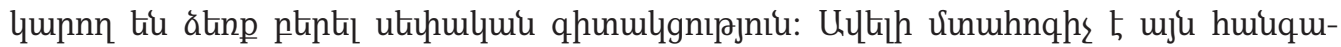

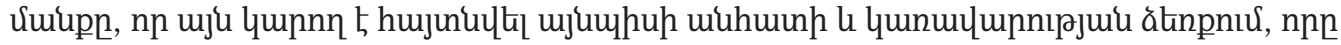

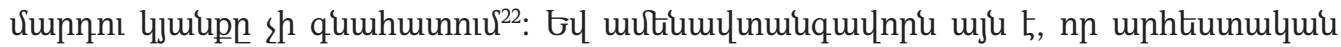

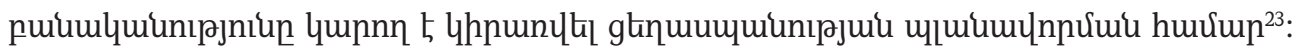

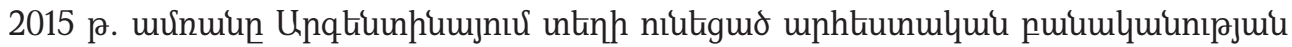

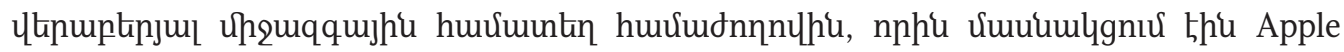

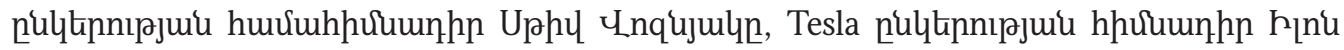

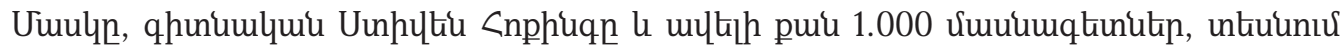

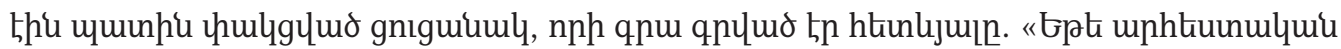

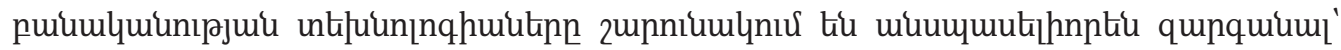

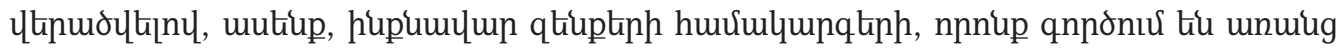

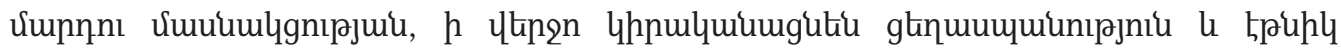
qunnuluthp» ${ }^{24}$ :

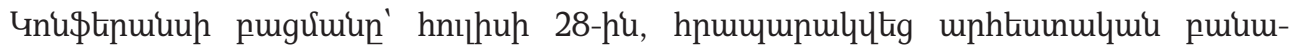

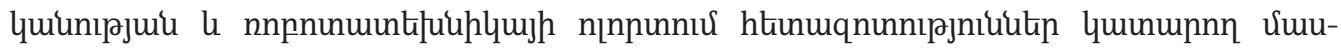

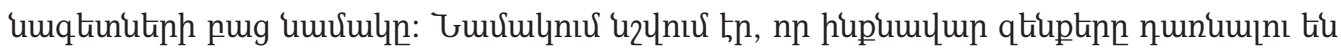

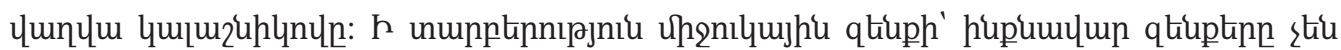

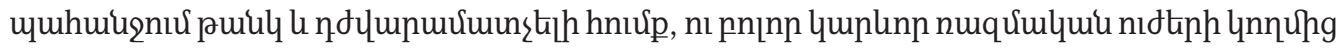

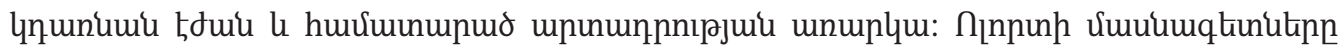

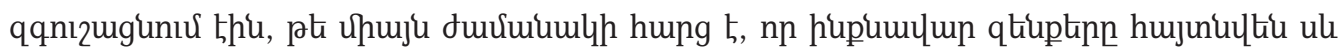

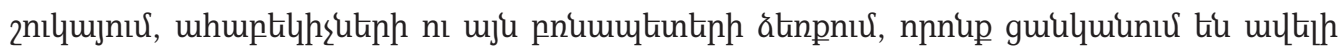

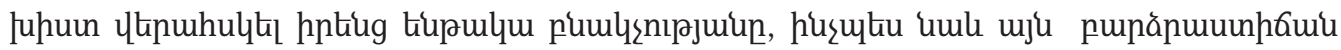

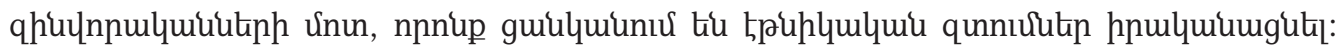

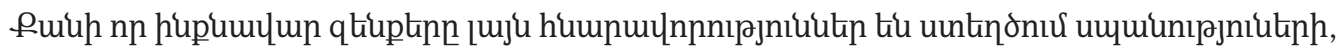

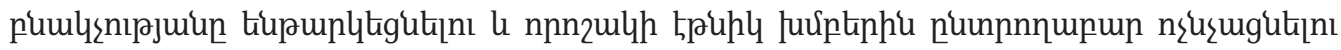

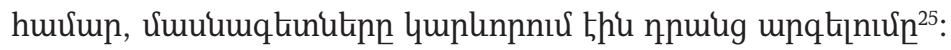

22 Bernard Marr, "Is Artificial Intelligence Dangerous? 6 AI Risks Everyone Should Know About," Forbes, November 19, 2018, https://www.forbes.com/sites/bernardmarr/2018/11/19/is-artificial-intelligencedangerous-6-ai-risks-everyone-should-know-about/\#1bedd0212404, nhunц니 5 14.05.2019:

23 Andrew Majot and Roman Yampolskiy, "Diminishing Returns and Recursive Self Improving Artificial Intelligence," in The Technological Singularity: Managing the Journey (The Frontiers Collection), ed. Victor Callaghan, James Miller, Roman Yampolskiy, Stuart Armstrong (Berlin: Springer: 2017), 142.

24 Jonathan Benson, "AI technology to eventually streamline the type of genocide and ethnic cleansing carried out by Planned Parenthood, experts warn," September 01, 2015, https://www.naturalnews. com/051010_artificial_intelligence_abortion_robots.html\#, nhunЦl

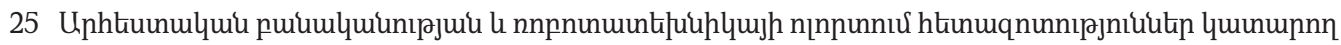

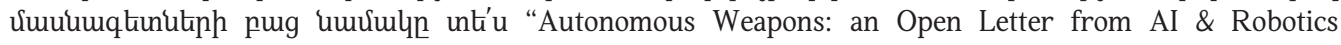




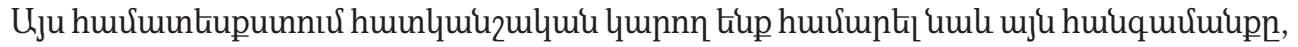

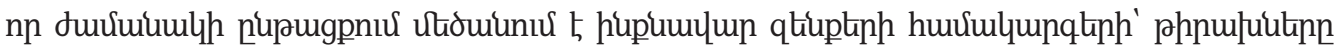

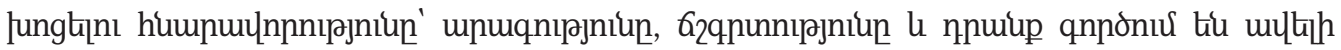

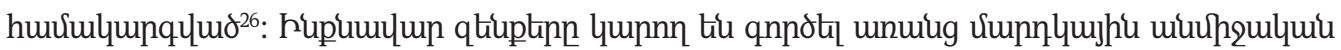

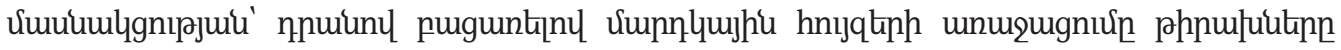

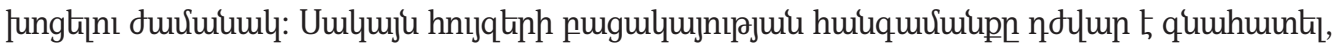

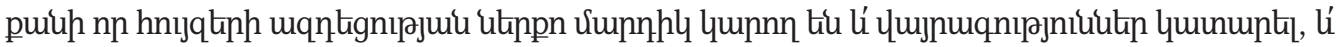

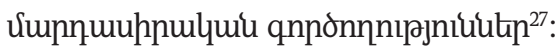

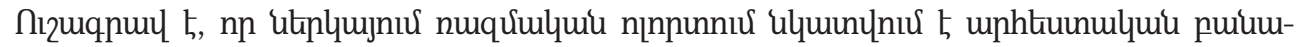

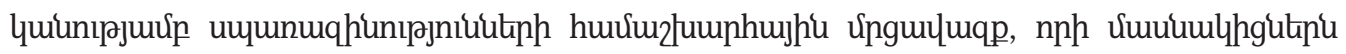

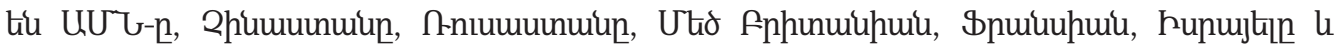

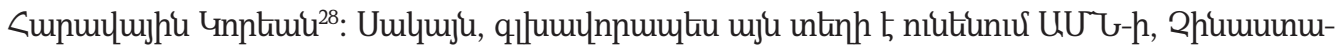
up l n nnumuunuuh ung $\mathrm{h}^{29}$ :

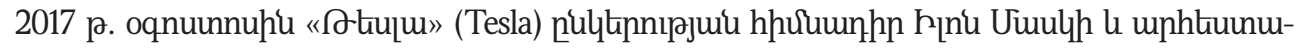

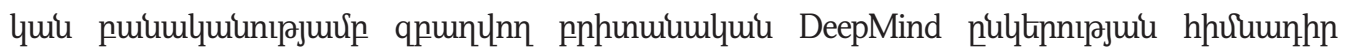

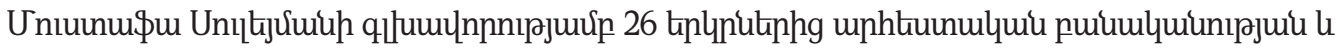

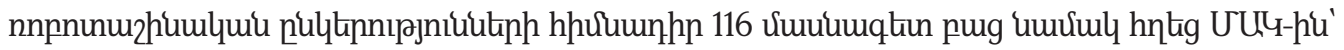

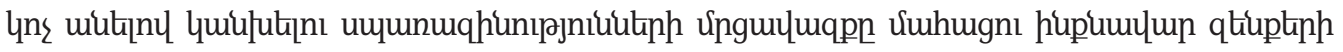

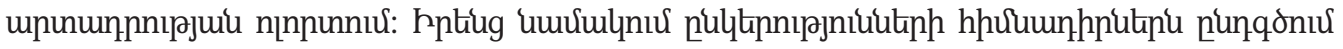

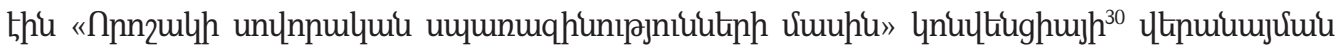

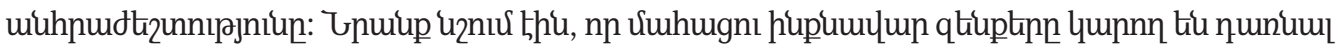

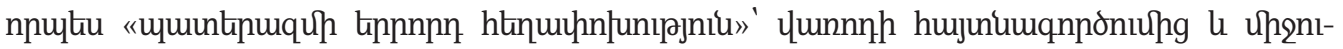

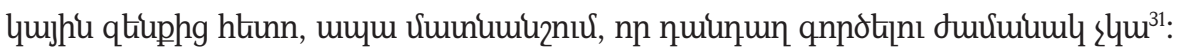

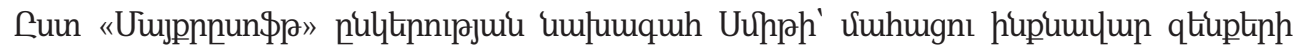

Researchers," https://futureoflife.org/open-letter-autonomous-weapons/?cn-reloaded=1, ๆhunцtı 13.05.2019:

26 Jayshree Pandya, “The Weaponization Of Artificial Intelligence,” Forbes, January 14, 2019, https://www. forbes.com/sites/cognitiveworld/2019/01/14/the-weaponization-of-artificial-intelligence/\#484da7953686, nhunltil 5 12.02.2020:

27 Paul Scharre, Army of None: Autonomous Weapons and the Future of War (New York, London: W. W. Norton \& Company, 2018), 232.

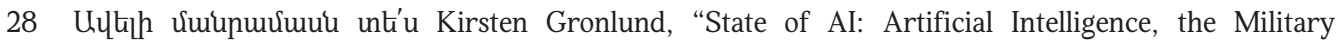
and Increasingly Autonomous Weapons," Future of Life Institute, May 9, 2019, https://futureoflife. org/2019/05/09/state-of-ai/, nhunltil 5 17.05.2019:

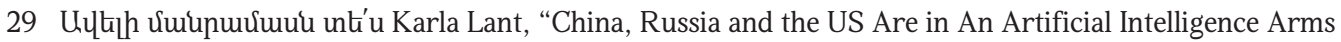
Race," September 12, 2017, https://futurism.com/china-russia-and-the-us-are-in-an-artificial-intelligencearms-race, nhunlthl 5 17.05.2019:

30 "Convention on Prohibitions or Restrictions on the Use of Certain Conventional Weapons Which May Be Deemed to Be Excessively Injurious or to Have Indiscriminate Effects," https://www.unog. ch/80256EDD006B8954/(httpAssets)/51609D467F95DD5EC12571DE00602AED/\$file/CONVENTION.pdf, nhunltal t 16.05.2019:

31 "An Open Letter to the United Nations Convention on Certain Conventional Weapons," https://www. cse.unsw.edu.au/ tw/ciair/open.pdf, nhunцlul 5 18.05.2019: 


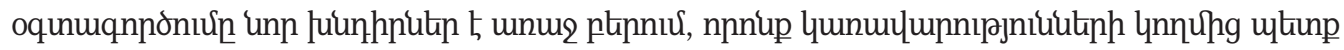

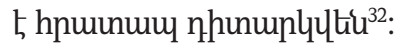

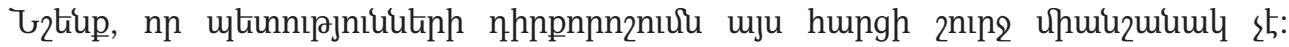

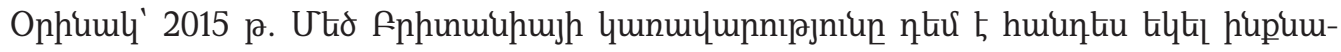

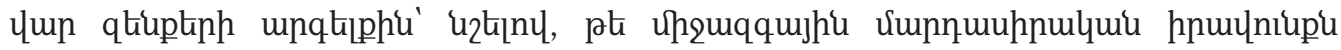

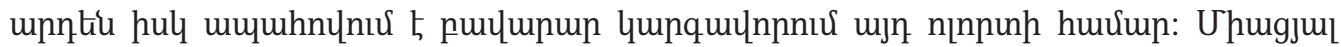

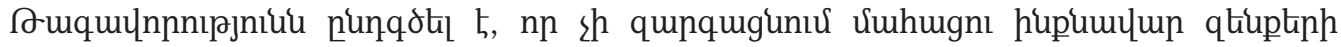

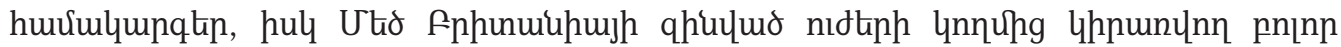

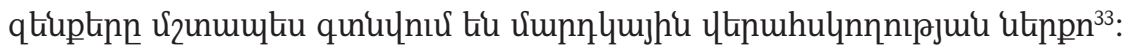

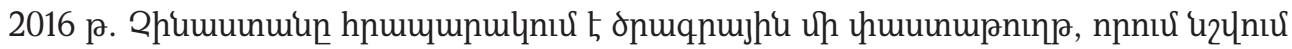

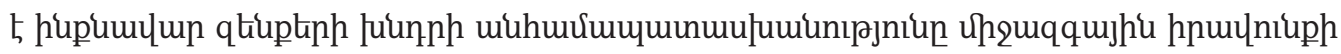

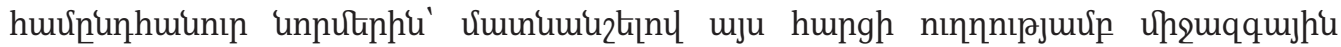

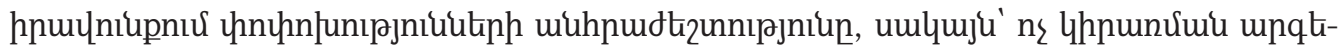

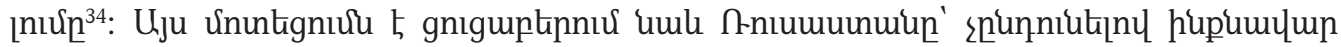

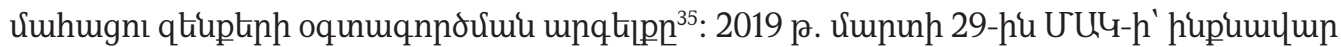

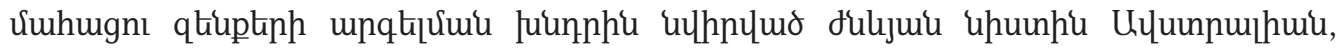

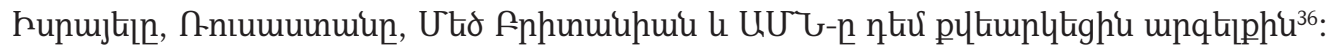

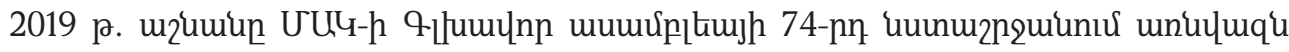

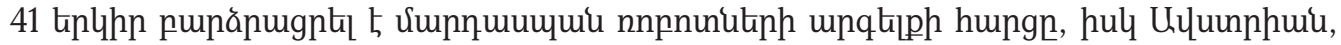

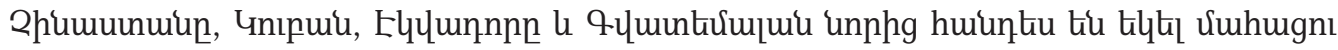

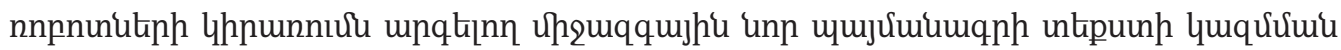

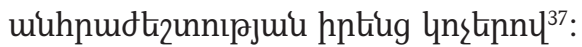

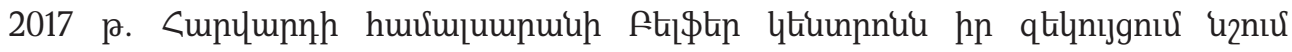

32 Wesley Hudson, "Killer robots 'unstoppable' rise will put public safety 'at risk' claims Microsoft chief," Daily Express and Sunday Express, Sepember 22, 2019, https://www.express.co.uk/news/uk/1181082/ killer-robots-latest-technology-news-microsoft-ai-lethal-autonomous-weapons?fbclid=IwAR2npnEYH1jlqbv YK_bsttXU08Dk1YpPMRYnuZDD-nBH46Trls-J5-9qXo8, nhunltıl 5 05.02.2020:

33 Owen Bowcott, "UK opposes international ban on developing "killer robots," The Guardian, April 13, 2015, https://www.theguardian.com/politics/2015/apr/13/uk-opposes-international-ban-on-developing-killerrobots, nhunltil 5 05.02.2020:

34 "The poistion paper submitted by the Chinese delegation to CCW 5th Review Conference," https:// www.unog.ch/80256EDD006B8954/(httpAssets)/DD1551E60648CEBBC125808A005954FA/\%24file/ China's+Position+Paper.pdf, nhunltıl 5 19.05.2019:

35 E\&T editorial staff, "Russia rejects potential UN 'killer robots' ban, official statement says," E\&T magazine, December 1, 2017, https://eandt.theiet.org/content/articles/2017/12/russia-rejects-potential-unkiller-robots-ban-official-statement-says/, uull'Group of Governmental Experts of the High Contracting Parties to the Convention on Prohibitions or Restrictions on the Use of Certain Conventional Weapons Which May Be Deemed to Be Excessively Injurious or to Have Indiscriminate Effects," November 10, 2017, https://admin.govexec.com/media/russia.pdf, nhunцlı 5 19.05.2019:

36 Gayle Damien, "UK, US and Russia among those opposing killer robot ban," The Guardian, March 29, 2019, https://www.theguardian.com/science/2019/mar/29/uk-us-russia-opposing-killer-robot-ban-un-ai,

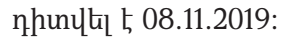

37 “High-level concerns on killer robots at UN," October 30 2019, https://www.stopkillerrobots.org/2019/10/ unga74/, nhunцlil 5 08.11.2019: 


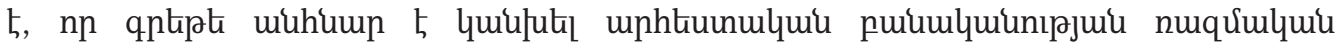

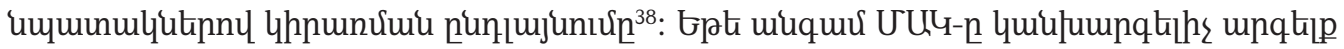

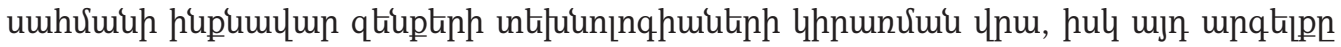

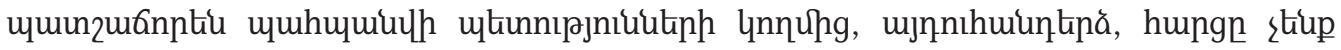

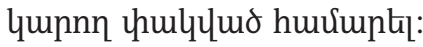

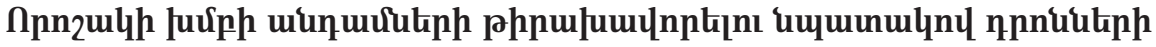 lhpunviuiu hupge}

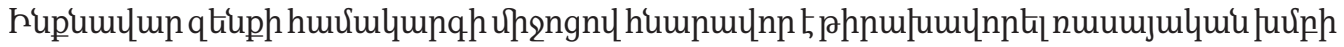

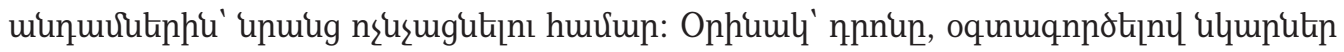

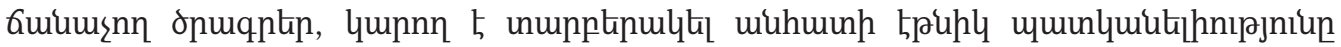

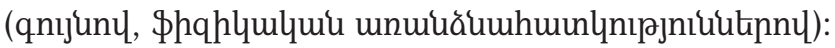

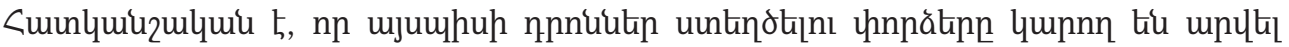

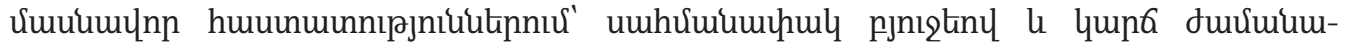

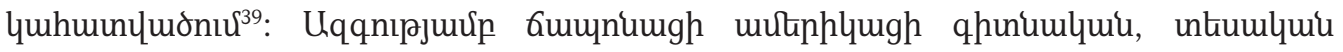

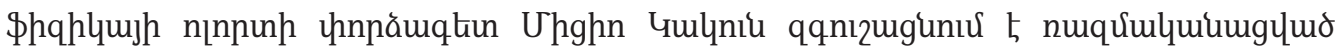

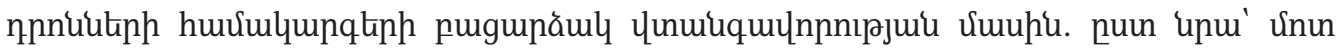

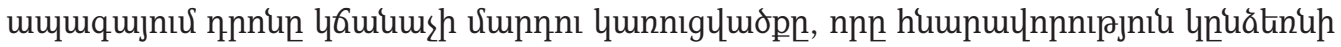

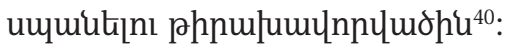

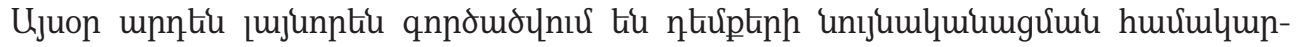

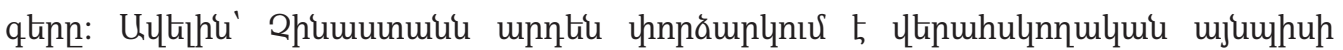

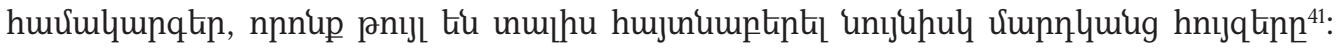

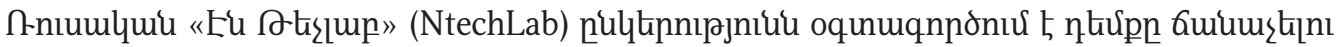

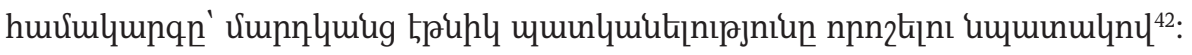

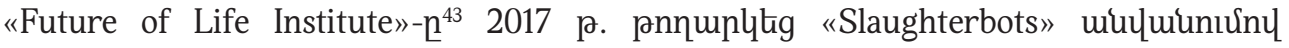

38 Greg Allen, Taniel Chan, Artificial Intelligence and National Security, Belfer Center for Science and International Affairs (Cambridge: Belfer Center for Science and International Affairs Harvard Kennedy School, 2017), 3, https://www.belfercenter.org/sites/default/files/files/publication/AI\%20NatSec\%20-\%20 final.pdf, nhunltil 5 22.05.2019:

39 Amir Husain, The Sentient Machine: The Coming Age of Artificial Intelligence (New York, London, Toronto, Sydney and New Delhi: Simon and Schuster, 2018), 106-107.

40 Jolene Creighton, "Physicist Michio Kaku Has Some Powerful Predictions for the Future," March 26, 2018, https://futurism.com/michio-kaku-prominent-futurist-predictions, nhunltl] 5 19.05.2019:

41 Adrian Potoroaca, "China is testing 'emotion recognition' systems in Xinjiang," TechSpot, November 4, 2019, https://www.techspot.com/news/82611-china-testing-emotion-recognition-systems-xinjiang.html?fbcl

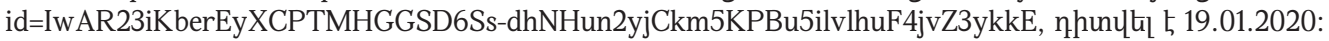

42 Ryan Daws, "Russian startup is building a controversial 'ethnicity-detecting' AI," AINews, May 25, 2018, https://artificialintelligence-news.com/2018/05/25/russian-ethnicity-detecting-ai/, nhunц니 5 19.05.2019:

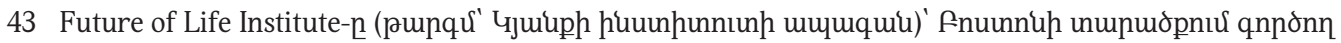

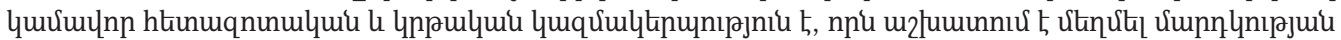

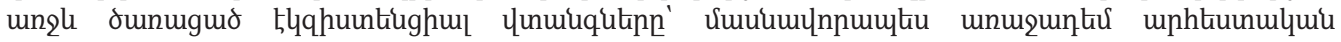
puiumumunipjuiu thqhuintiughul nhulp: 


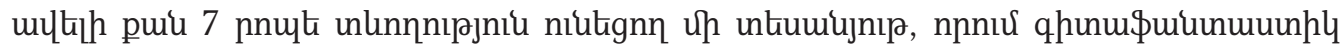

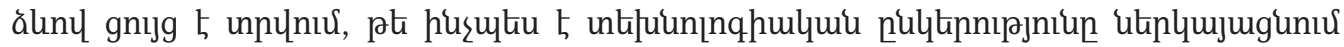

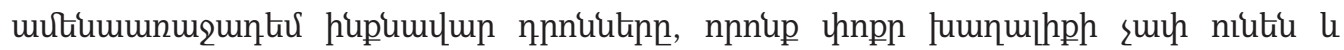

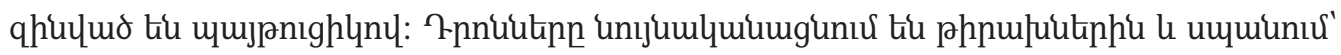

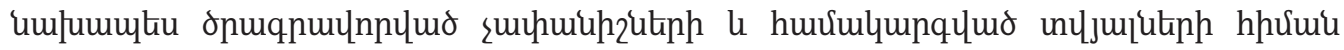

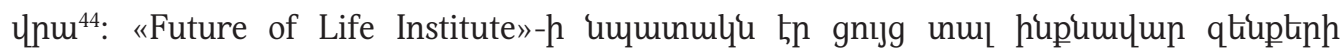

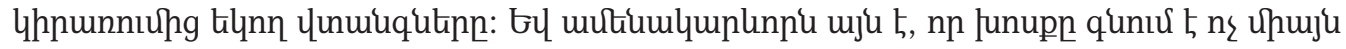

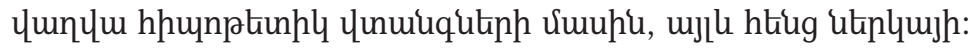

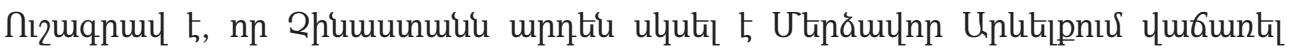

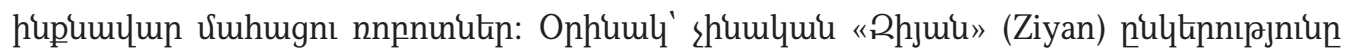

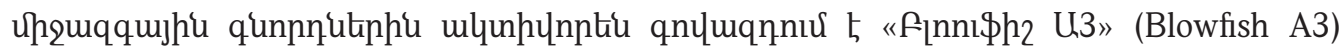

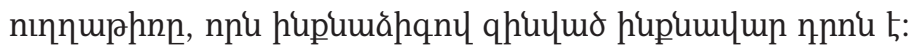

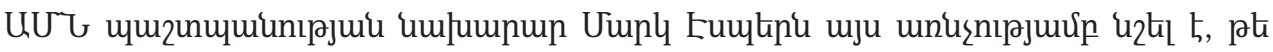

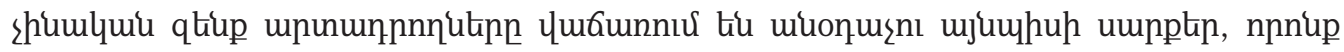

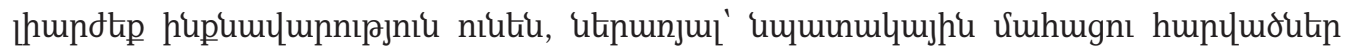

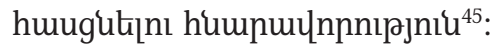

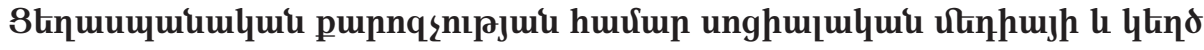 unkumunnothp lhpunviuiu juinhpe}

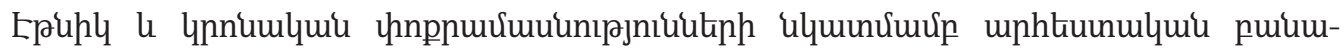

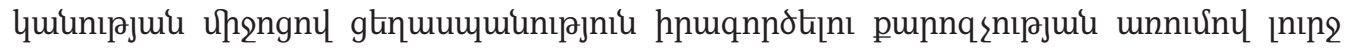

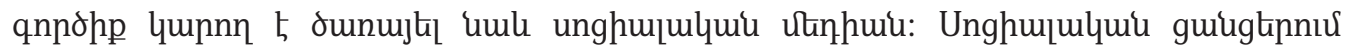

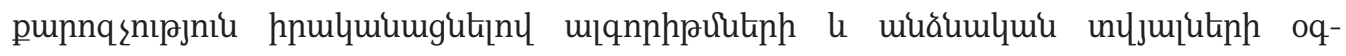

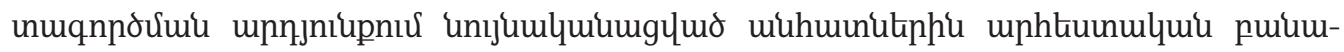

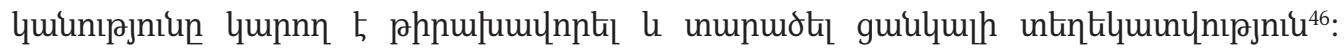

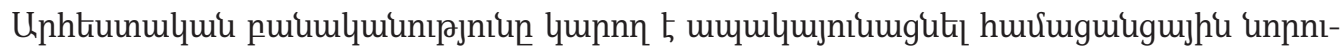

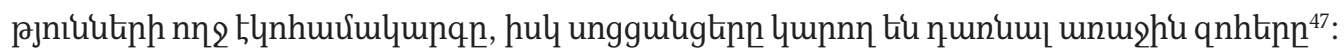

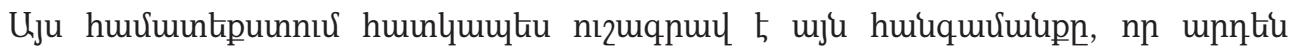

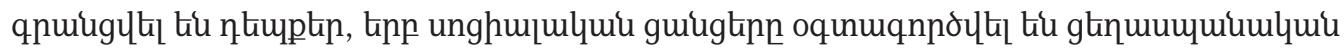

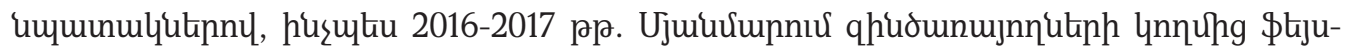

44 Future of Life Institute, "Slaughterbots," November 13, 2017, https://www.youtube.com/ watch?v=HipTO_7mUOw, nhunцlı 5 15.09.2019:

45 Patrick Tucker, "SecDef: China Is Exporting Killer Robots to the Mideast," Defense One, November 5, 2019, https://www.defenseone.com/technology/2019/11/secdef-china-exporting-killer-robots-mideast/1611 00/?oref=DefenseOneFB\&fbclid=IwAR30HzhnTAAzJH-LUggx4leuTuR71PdLECunjhzinNnwnxDVplJJ7OH EA7s, nhunцti 5 29.09.2019:

46 Bernard Marr, "Is Artificial Intelligence Dangerous? 6 AI Risks Everyone Should Know About," Forbes, November 19, 2018, https://www.forbes.com/sites/bernardmarr/2018/11/19/is-artificial-intelligencedangerous-6-ai-risks-everyone-should-know-about/\#1bedd0212404, nhunlkㅣ 5 19.01.2020:

47 Victor Tangerman, Elon Musk, “'Advanced Al' Will Manipulate Social Media,” 26 September 2019, https://futurism.com/the-byte/elon-musk-ai-manipulate-social-media, nhunlthl 5 05.11.2019: 


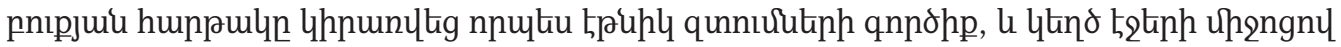

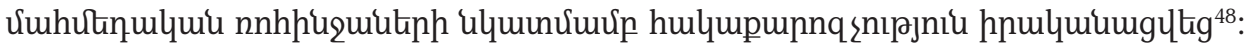

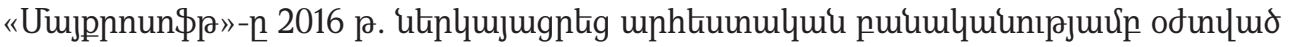

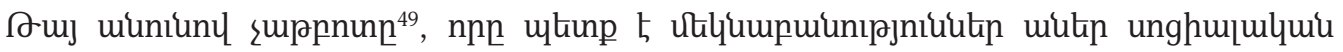

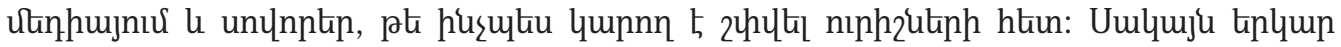

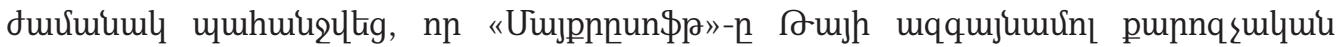

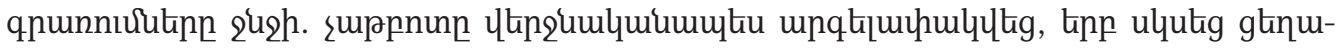

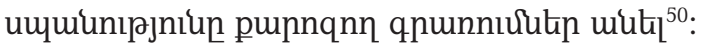

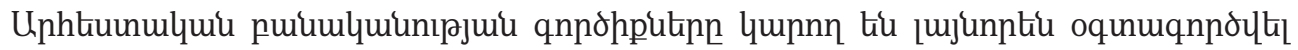

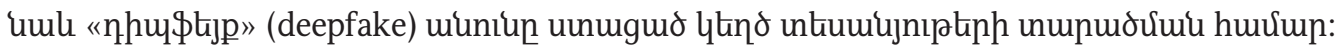

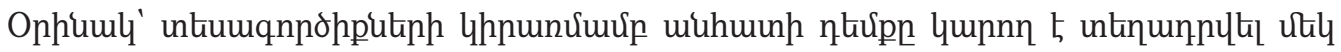

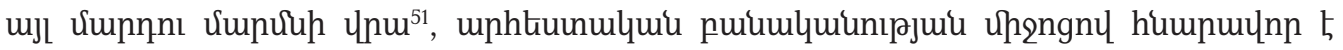
punophumultal uml ưunnns àmjup 52 :

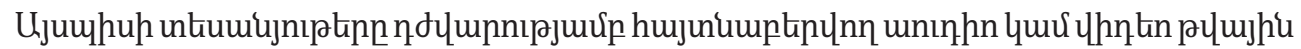

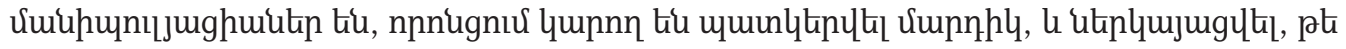

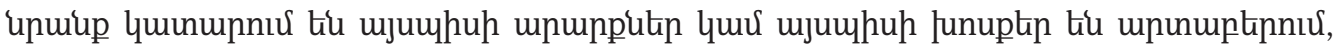

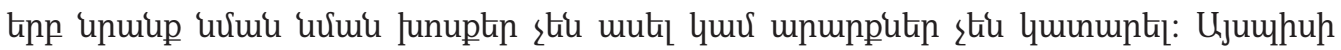

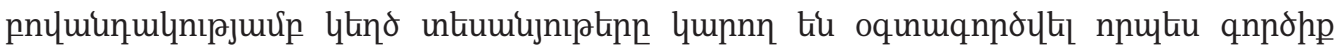

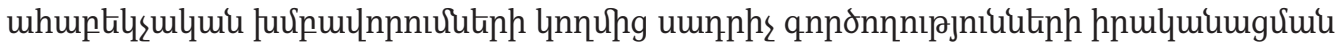

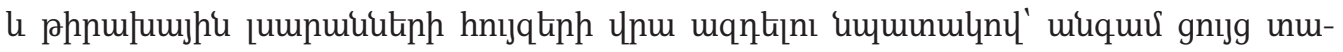

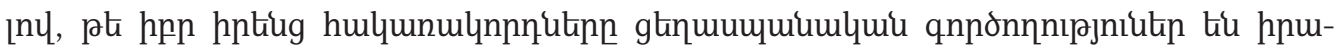

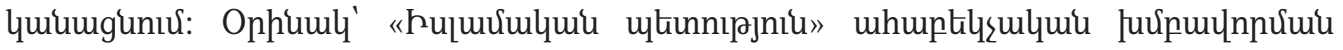

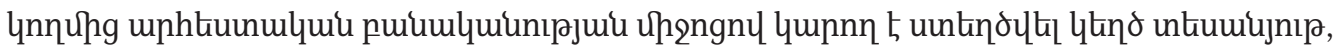

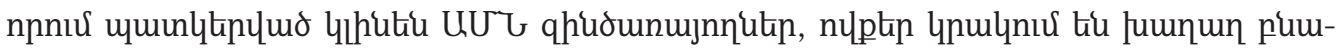

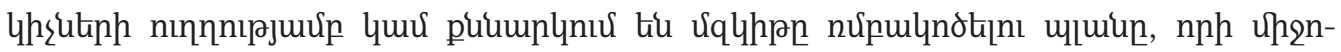

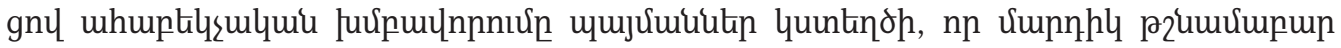

48 Paul Mozur, "A Genocide Incited on Facebook, With Posts From Myanmar's Military," New York Times, October 15, 2018, https://www.nytimes.com/2018/10/15/technology/myanmar-facebook-genocide. html, nhunltil 5 08.03.2020:

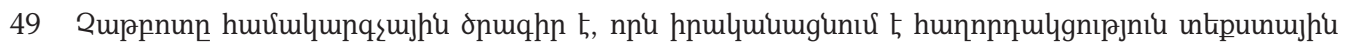

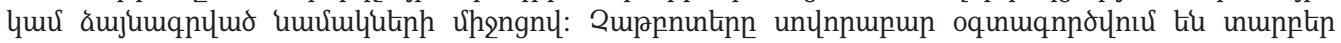

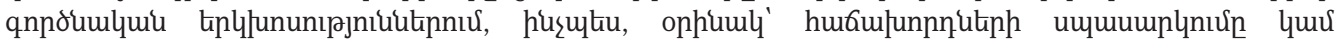
untintlumunцnıpjnitu unuiumin:

50 James MacDonald, "Microsoft is deleting its AI chatbot's incredibly racist tweets," Business Insider, April 15, 2016, https://daily.jstor.org/when-the-ai-promotes-genocide/, nhunltal 5 23.05.2019: St'u umlu Rob Price, "Microsoft is deleting its AI chatbot's incredibly racist tweets," Business Insider, March 24, 2016, https://www.businessinsider.com/microsoft-deletes-racist-genocidal-tweets-from-ai-chatbot-tay-20163?r=UK\&IR=T, nhunuli 5 28.05.2019:

51 Kevin Roose, "Here Come the Fake Videos, Too," New York Times, March 4, 2018, https://www. nytimes.com/2018/03/04/technology/fake-videos-deepfakes.html, nhunцtㅣ th 28.05.2019:

52 Bahar Gholipour, "New AI Tech Can Mimic Any Voice," Scientific American, May 2, 2017, https:// www.scientificamerican.com/article/new-ai-tech-can-mimic-any-voice/, nhunltl 5 , 29.05.2019: 


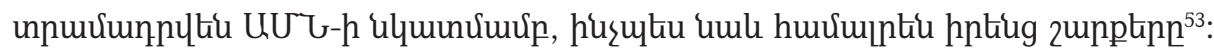

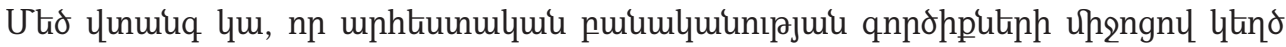

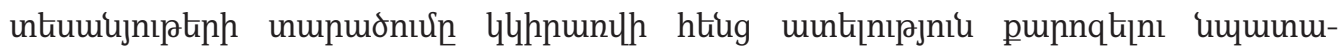

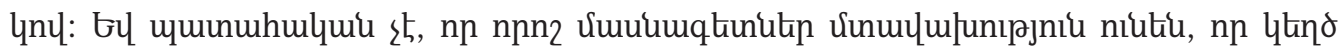

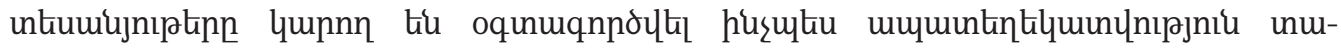

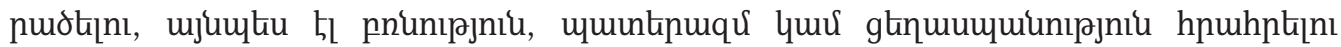

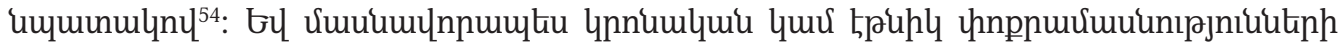

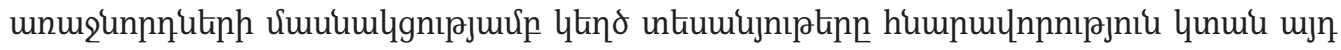

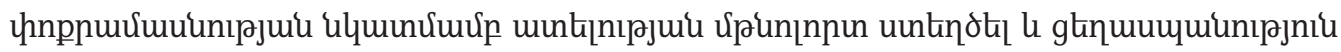
hpuhpl ${ }^{55}$ :

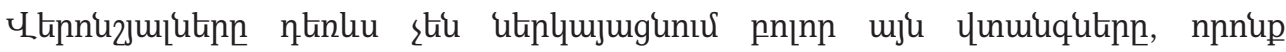

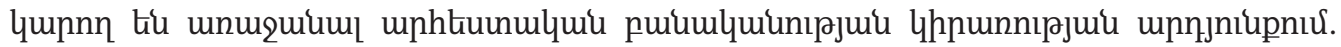

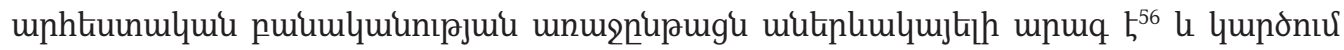

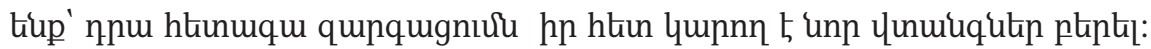

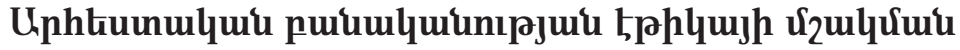 uuhpudtizunnıрjnitup}

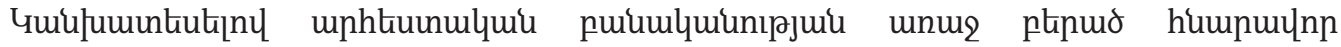

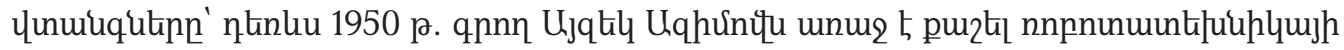

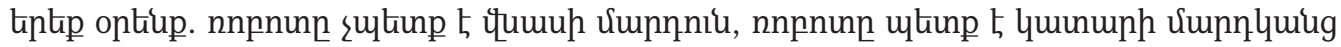

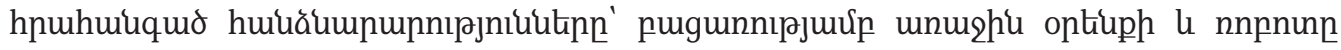

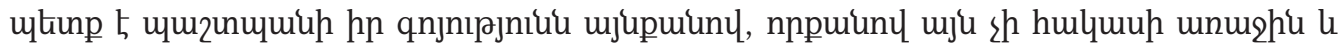
Łplnnpn optuputiphus ${ }^{57}$ :

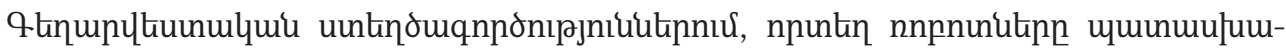

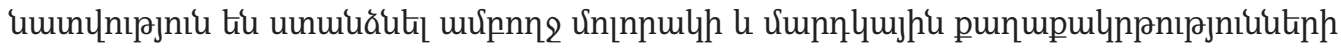

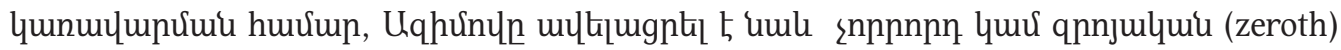

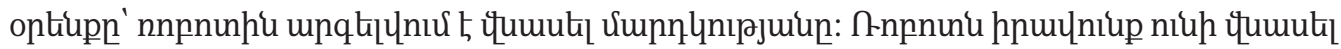

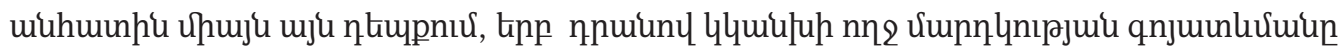

53 Robert Chesney and Danielle Citron, "Deepfakes and the New Disinformation War: The Coming Age of Post-Truth Geopolitics," Foreign Affairs, January/February 2019, https://www.foreignaffairs.com/articles/ world/2018-12-11/deepfakes-and-new-disinformation-war, nhunlkil 5 28.01.2020:

54 Council on Foreign Relations, “The Threat of Deep Fakes,” May 31, 2019, https://www.youtube.com/ watch?v=zhf2X1RyIWE, nhunltil 5 20.09.2019:

55 John Loeffler, “AI Deepfakes Are Now Easier to Make Than Ever, Pointing to Ominous Future," Interesting Engineering, June 11, 2019, https://interestingengineering.com/ai-deepfakes-are-now-easier-tomake-than-ever-pointing-to-ominous-future, nhunllil 5 28.01.2020:

56 Stephen Yuen, "Elon Musk on Artificial Intelligence: 'The pace of progress in artificial intelligence is incredibly fast," "November 18, 2014, https://www.thesavvytechs.com/2014/11/18/elon-musk-artificialintelligence-pace-progress-artificial-intelligence-incredibly-fast/, nhunlthl 5 28.05.2019:

57 Isaac Asimov, “Runaround.” I, Robot (New York City: Doubleday, 1950), 40. 


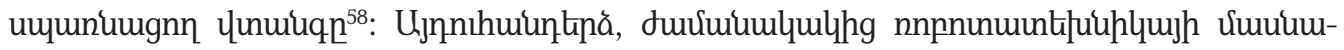

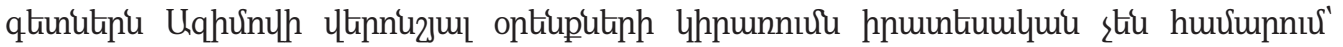

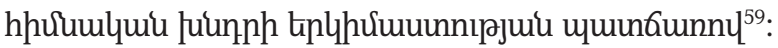

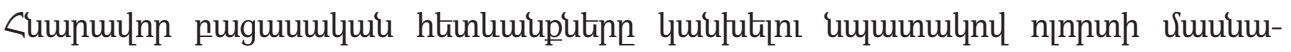

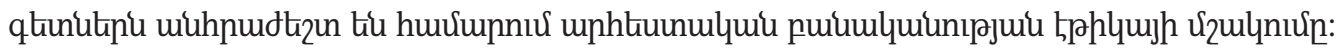

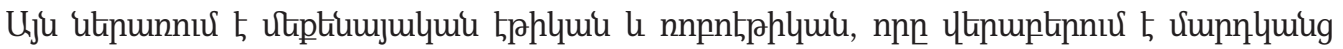

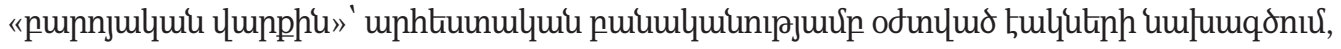
quinnigniu, oqunuqnnoniu:

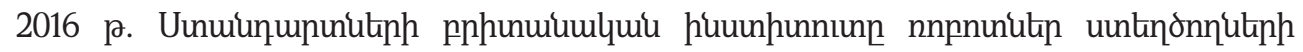

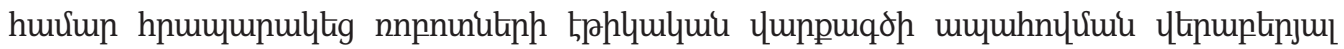

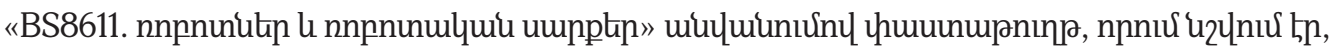

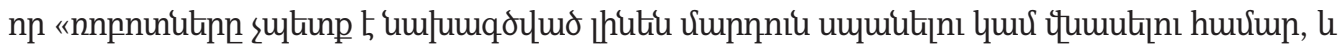
ujn hungnư n

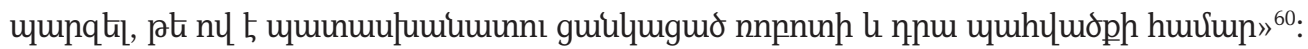

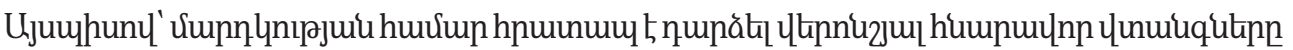

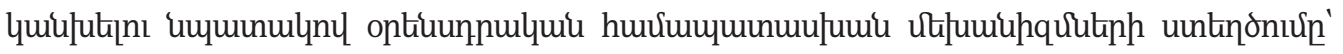

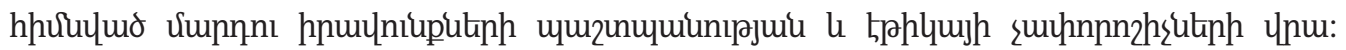

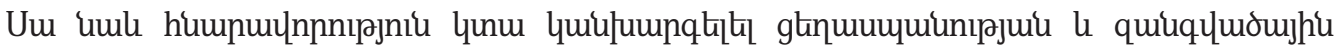

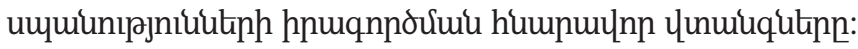

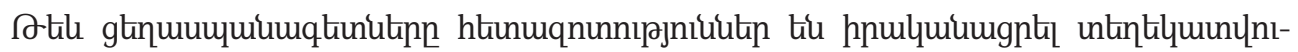

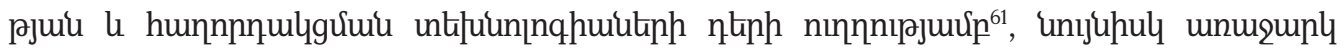

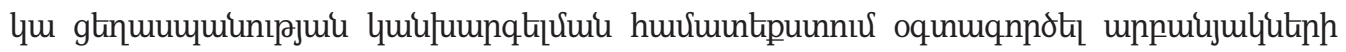

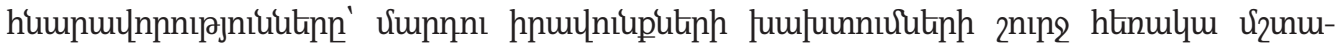

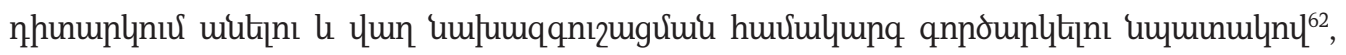

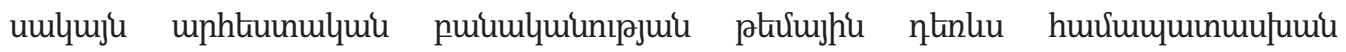

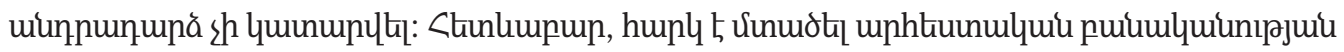

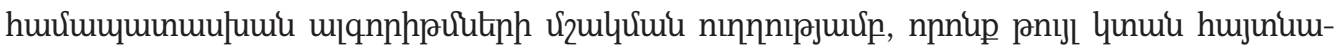

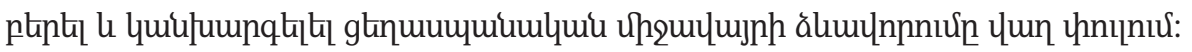

58 Keith Abney, "Robotics, Ethical Theory, and Metaethics: A Guide for the Preplexed," in Robot Ethics: The Ethical and Social Implications of Robotics, ed. Patrick Lin, Keith Abney, George A. Beke (Cambridge, Massachusetts, London: MIT Press, 2012), 43.

59 McCauley Lee, "AI Armageddon and the Three Laws of Robotics," Ethics and Information Technology 9, no.2 (2007): 153-164.

60 Amit Ray, Compassionate Artificial Intelligence: Frameworks and Algorithms, Compassionate AI Lab (An Imprint of Inner Light Publishers, 2018), 46-47.

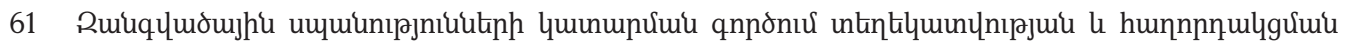

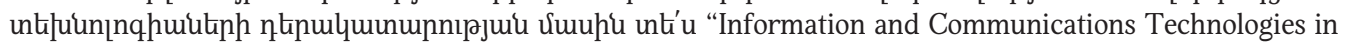
Mass Atrocities Research and Response," Genocide Studies and Prevention 11, no. 1, (2017): 128.

62 Andrew Marx, "Using Satellites to Detect Mass Human Rights Violations: A Call for International Community to Implement an Early Warning Detection System," in Last Lectures on the Prevention and Intervention of Genocide, ed. Samuel Totten (London and New York: Routledge, 2018), 171-179. 
Narek M. Poghosyan

$\mathrm{PhD}$ in History

\section{THE DEVELOPMENT OF ARTIFICIAL INTELLIGENCE AND RISKS FOR THE IMPLEMENTATION OF GENOCIDE AND MASS KILLINGS}

\section{SUMMARY}

Key words: Artificial intelligence, lethal autonomous weapons, arms race, robots, genocide, social media, fake videos, artificial intelligence ethics.

This article illustrates the fact that the accelerating pace of technological development in recent years, in particular the use of artificial intelligence (AI) has raised serious concerns among experts that it, along with its advantages, can pose many dangers to mankind when machines think and make decisions for them. Particularly risky is that the development of $\mathrm{AI}$ and autonomous weapons can be used to target certain national, religious and racial groups, thereby increasing the risk of genocide and mass killings.

In the present day, when the global arms race using $\mathrm{AI}$ is a reality, many technologists are turning their attention to banning lethal autonomous weapons. In addition, in order to prevent the potential negative consequences of AI development, industry professionals have suggested the need to develop an AI code of ethics.

The creation of appropriate legislative mechanisms based on ethics and the protection of human rights has already become an urgent matter for mankind to prevent the possible risks posed by the development of robotics and artificial intelligence technology.

Since artificial intelligence is used to detect and prevent various types of crime, it is therefore necessary to use the opportunities provided by it to prevent genocide and mass murder.

Нарек М. Погосян

кандидат исторических наук

\section{РАЗВИТИЕ ИСКУССТВЕННОГО ИНТЕЛЛЕКТА И РИСКИ ДЛЯ ОСУЩЕСТВЛЕНИЯ ГЕНОЦИДА И МАССОВЫХ УБИЙСТВ}

\section{PEЗЮME}

К^ючевые слова: искусственный интеллект, смертоносное автономное оружие, гонка вооружений, роботы, геноцид, дроны, социальные сети, фальшивые видео, этика искусственного интеллекта.

В статье показано, что ускоряющиеся темпы развития технологий в последние годы, в частности использование искусственного интеллекта, вызывают серьезные 
опасения у экспертов, что он, наряду с его преимуществами, может создать много опасностей для человечества, когда машины думают и принимают решения для себя. Особенно рискованным является тот факт, что разработка искусственного интеллекта и автономного оружия может использоваться для нацеливания на определенные национальные, религиозные, расовые группы, что повышает риск геноцида и массовых убийств.

В настоящее время, когда глобальная гонка вооружений с использованием искусственного интеллекта становится реальностью, многие технологи обращают свое внимание на запрет смертоносного автономного оружия. Кроме того, чтобы предотвратить возможные негативные последствия развития искусственного интеллекта, профессионалы отрасли предложили разработать этику искусственного интеллекта.

Создание соответствующих законодательных механизмов, основанных на защите прав человека и этики, уже стало насущной задачей для человечества, чтобы предотвратить возможные риски, связанные с развитием робототехники и технологий искусственного интеллекта.

Поскольку искусственный интеллект используется для обнаружения и предотвращения различных видов преступлений, поэтому необходимо использовать возможности, предоставляемые искусственным интеллектом для предотвращения геноцида и массовых убийств. 